

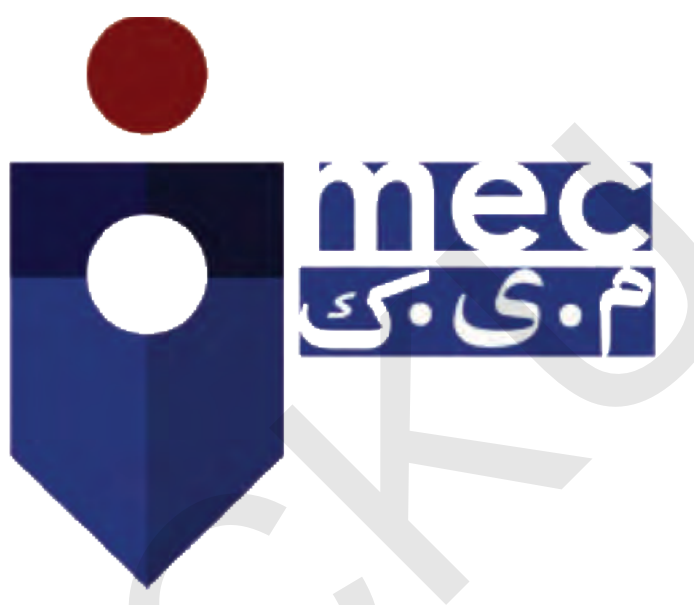

كميته مستقل مشترك نظارت و ارزيابى مبارزه عليه فساد ادارى طور مستقلانه از تلاشهاى

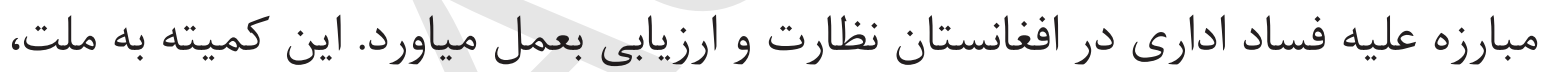

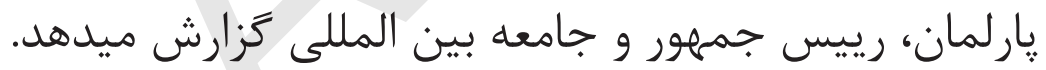



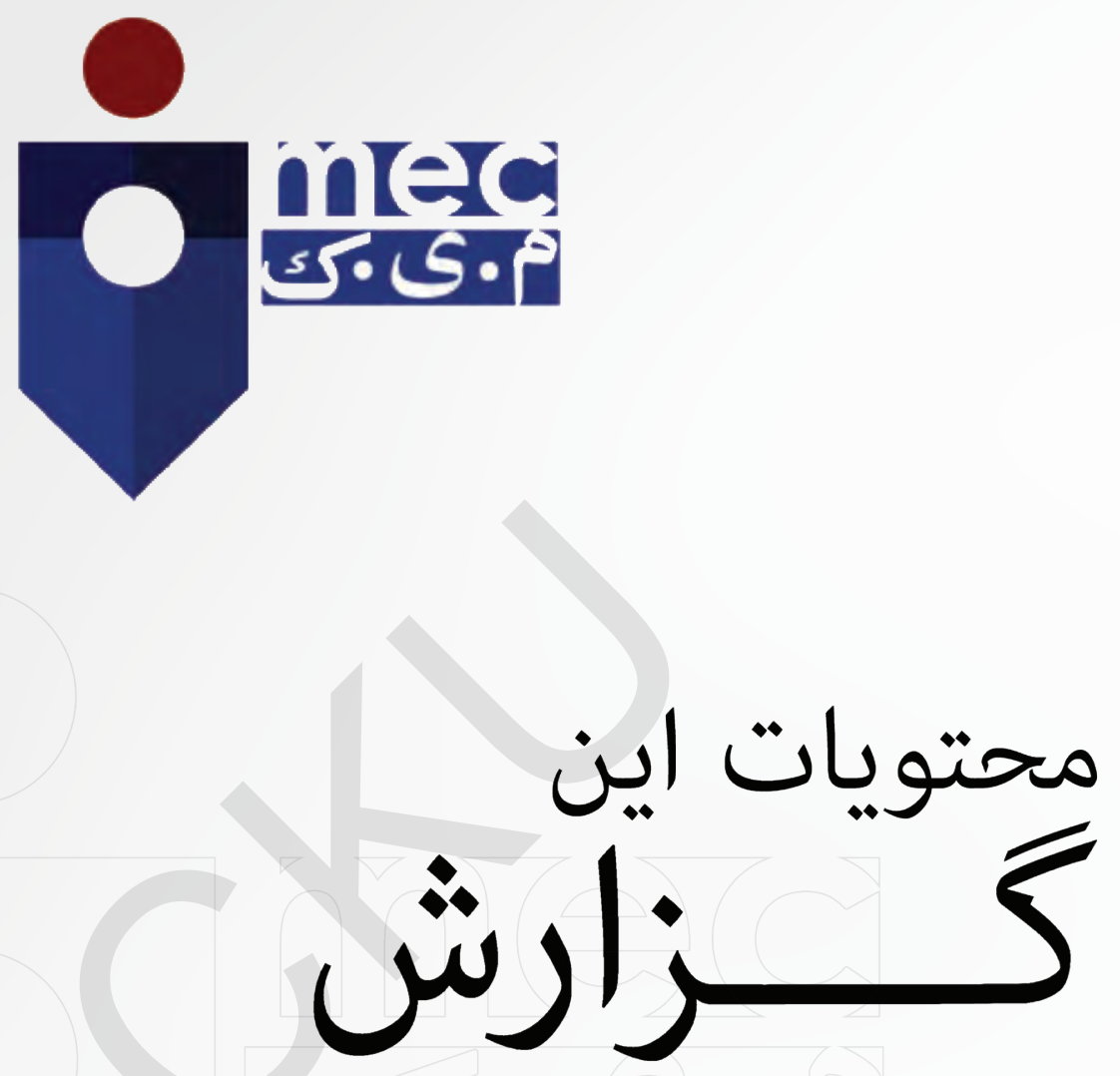

$\omega$

V

V

9

IT

Ir

If

10

IV

$$
\text { فيام رئيس كميته }
$$$$
\text { تحقيق عامه در مورد برنامئ كارد-اف }
$$
بررسى یِلان هاى مبارزه عليه فساد ادارى وزارتخانه ها ه مين ماموريت كميته نظارت و ارزيابى ساير فعاليت هاى كميتهُ نظارت و ارزيابى فساد ادارى در افغانستان: مرورى بر اخبار اين ربع معرفى عضو جديد كميته نظارت و ارزيابى 
"براى موفقيت در امر مبارزه عليه فساد

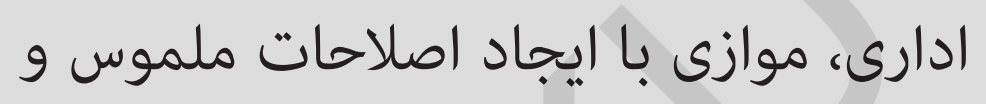
تلاش ها در راستاى تعقيب عدلى و قضائى، نياز داريم تا به طور جدى روى تحكيم

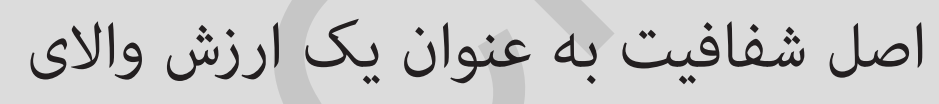
اجتماعى قَركز فاييم.."

هيلينه ملكيار، رئيس كميتهُ نظارت و ارزيابى مبارزه عليه فساد ادارى 


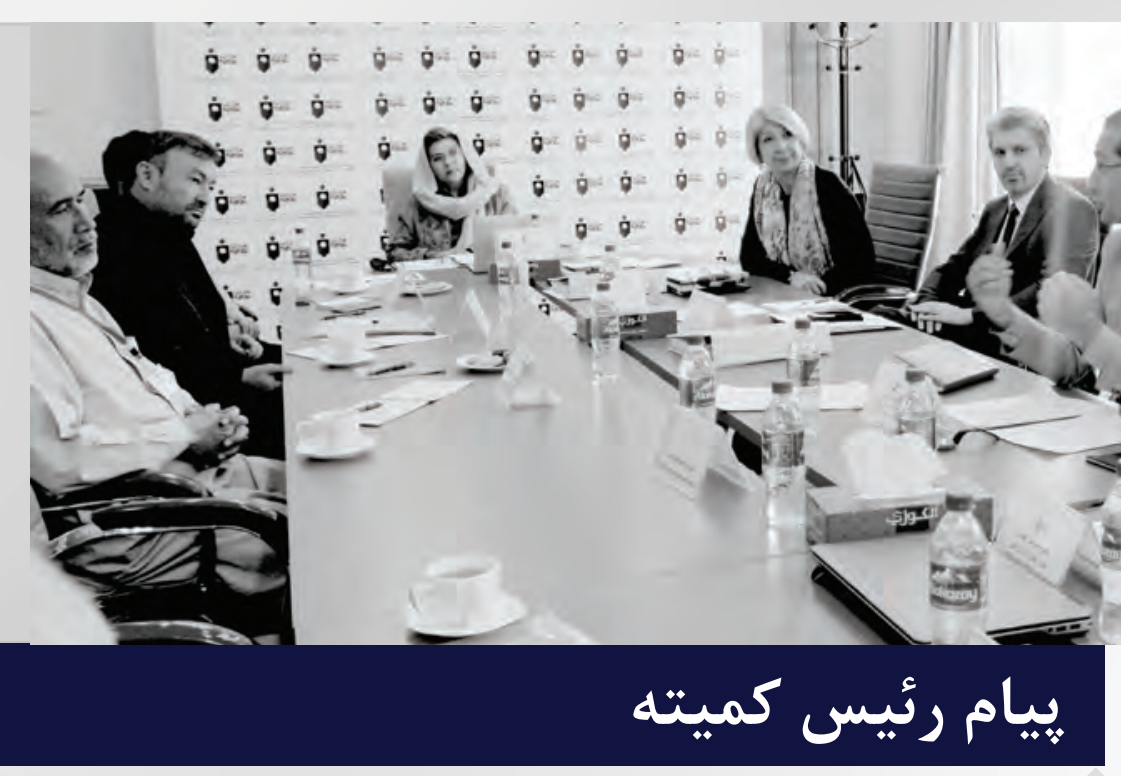

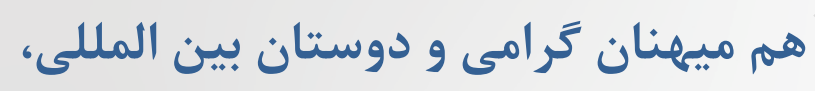

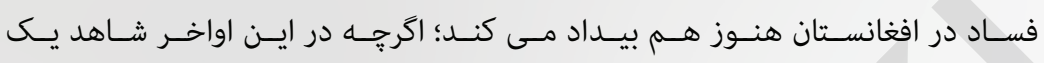

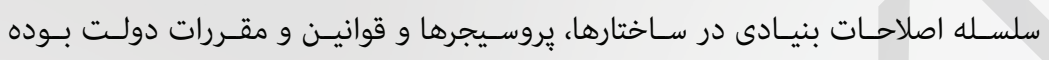

$$
\text { ايسم. }
$$

تحليلكَران و سياسـيون جُشـم انـداز مبـارزه بـا فسـاد را در كشـور را بـا ناباورى مـى نكرند.

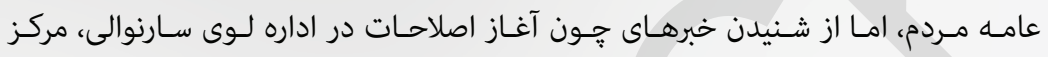

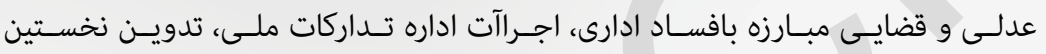

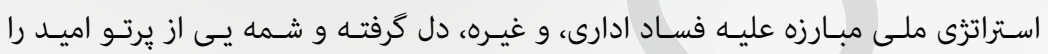

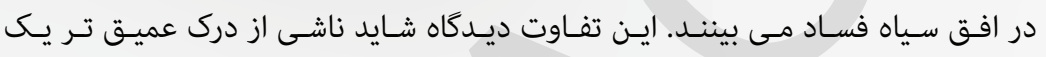

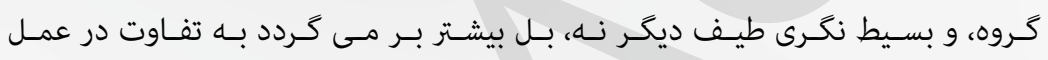

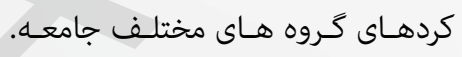

كميتــه مسـتقل مشـترك نظـارت و ارزيابـى مبـارزه عليـه فسـاد ادارى مانــــ هـر نهـاد يـا

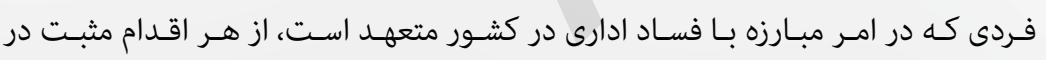

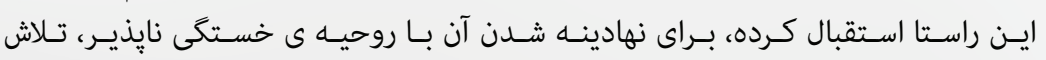

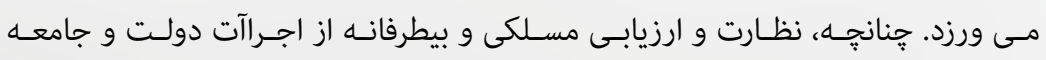

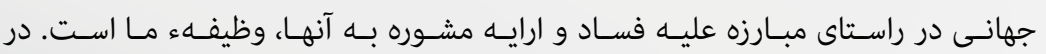

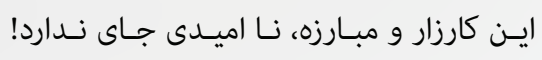

كفتم كه يافت مى نشود، جسته ايم ما كفت آنكه يافت مى نشود، آنم آرزوست

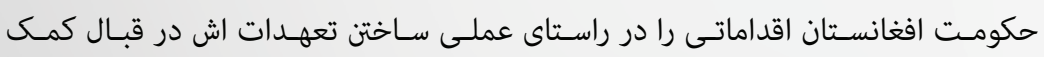

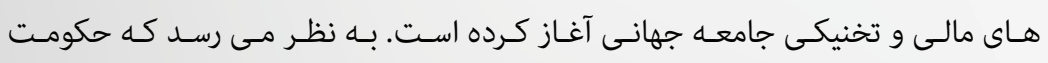

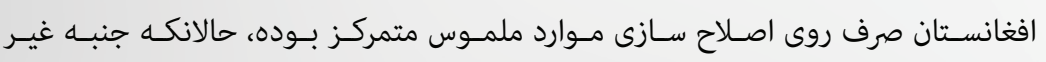

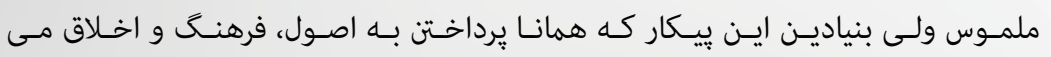

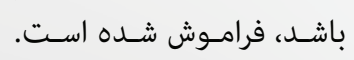

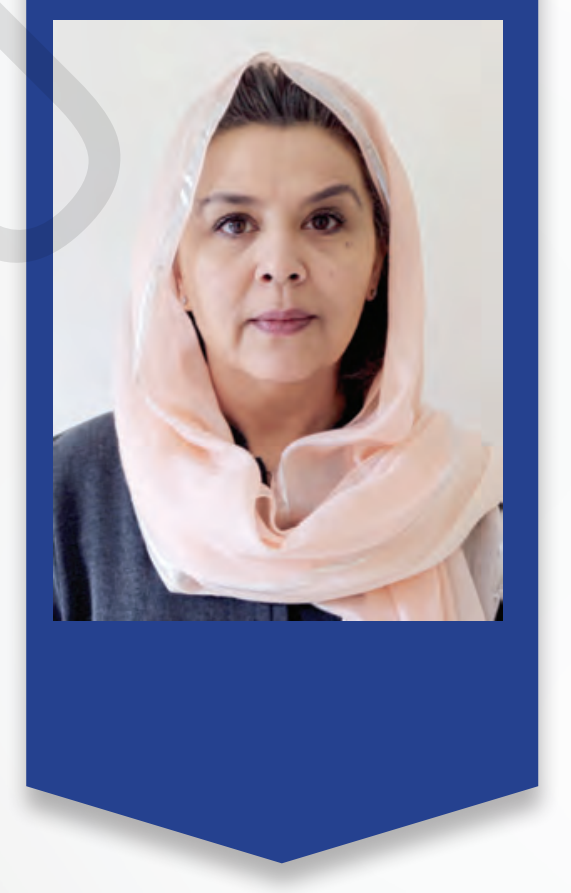




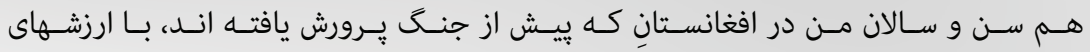

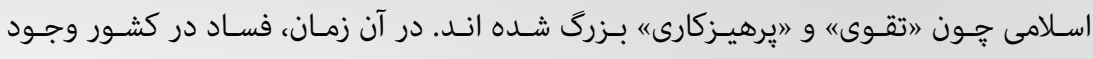

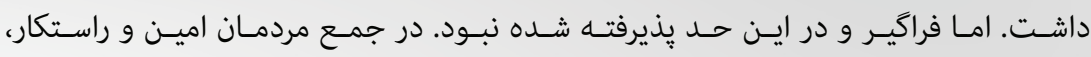

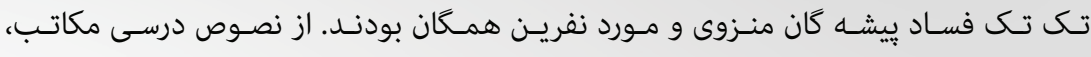

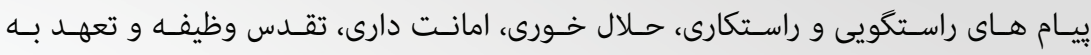

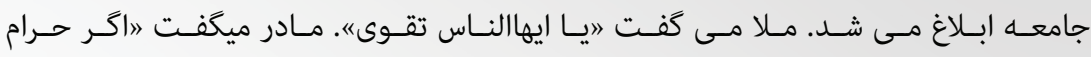

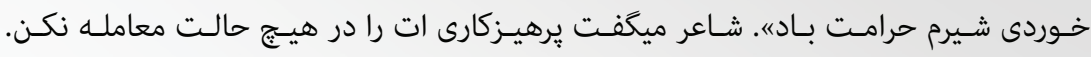
لكهـ ونه مســتقيم يֶه خِل مكان يم كه خـزان را باندي راشـي كه بهار

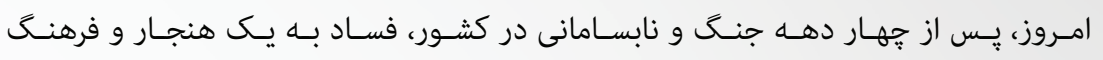

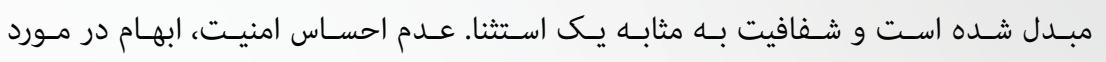

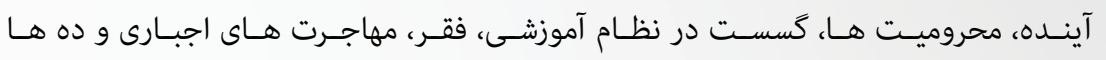

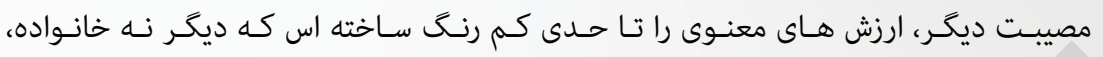

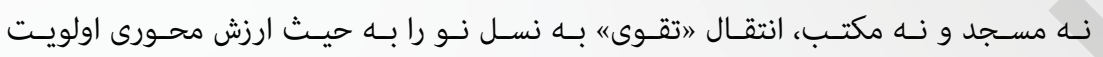
مـى دهـد.

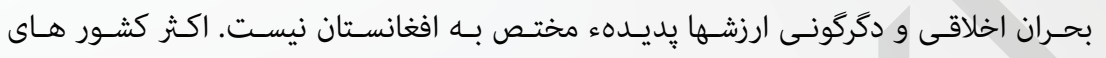

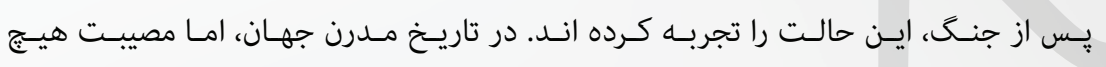

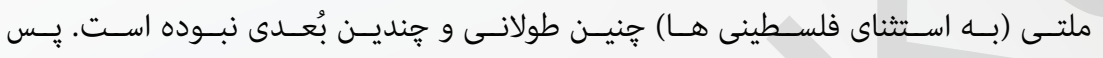

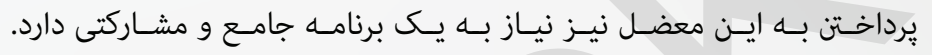

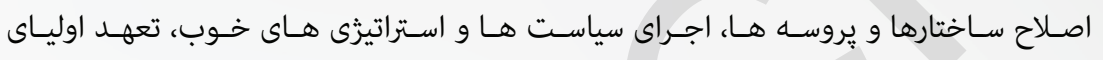

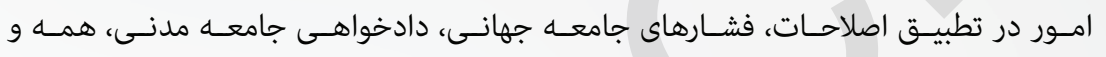

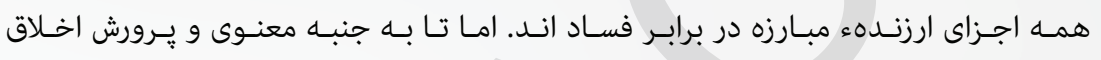

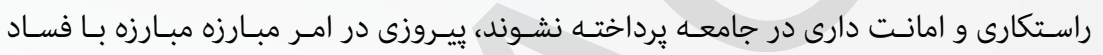
بعيـد مـى فايـد.

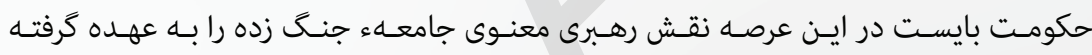

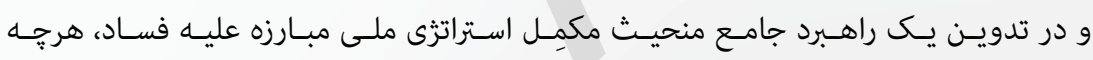

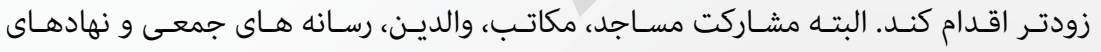

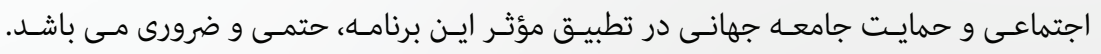

به اميد فرداى بهتر!

\section{هيلينه ملكيار}

رييس كميتهُ ظارت و ارزيابى مبارزه عليه فساد ادارى

"جنبه غير ملموس ولى بنيادين اين غير ملمونان

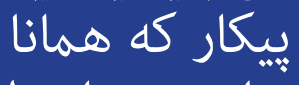

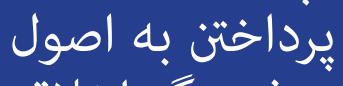

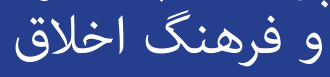
ميباشل، فراموش شده است. " 


\section{فعاليت هاى اخير

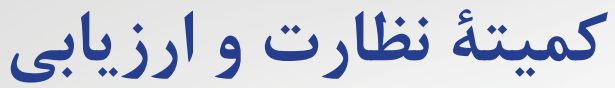

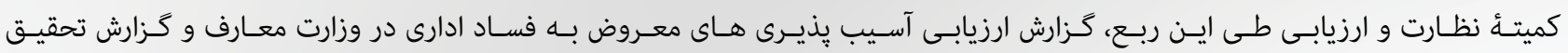

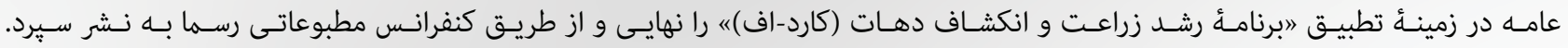

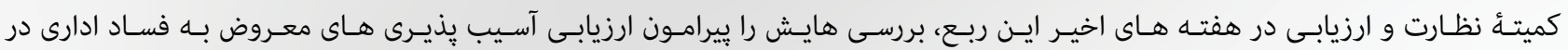

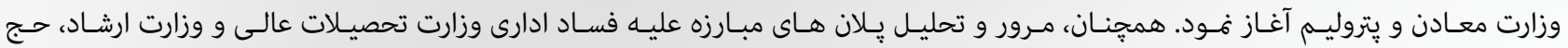
و اوقـاف را نيـز نهايـى نـــود.

\section{فساد در معارف

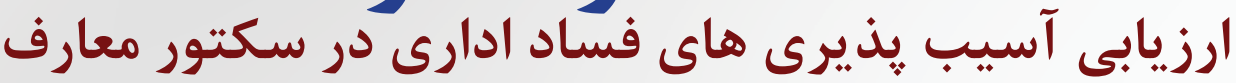

9 ا مصاحبـه بـا كارمنــدان ولايتـى معـارف، V9 مصاحبـه بـا نهـاد هـاى

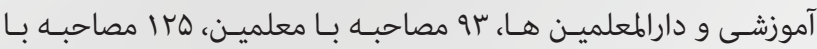

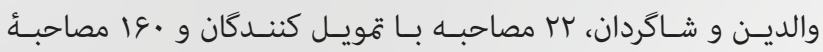

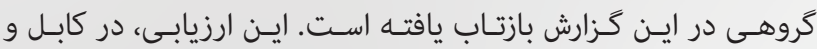

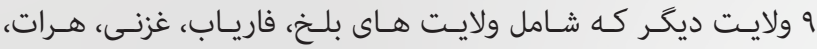

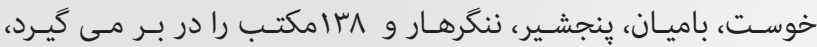

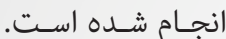

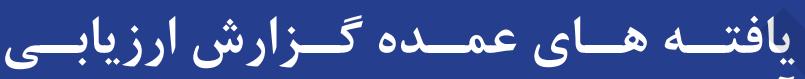

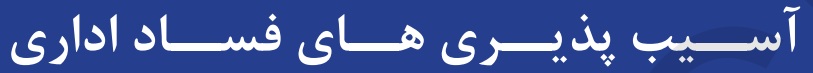

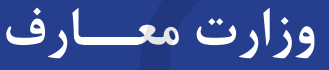

كميتـهُ نظـارت و ارزيابـى در ايـن ارزيابـى، جس مـورد مختلـف فســاد

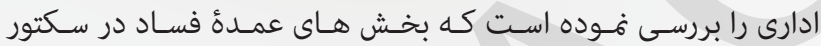

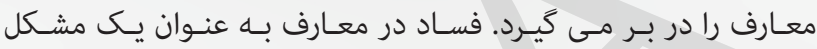

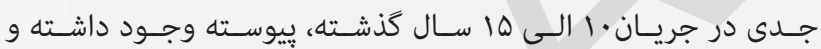

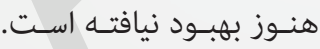

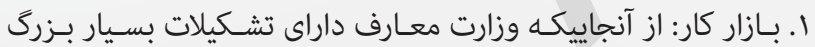

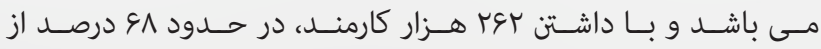

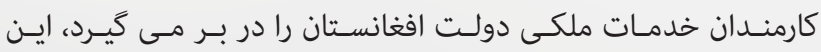

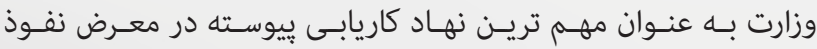

كميتــ نظـارت و ارزيابـى بـه تاريـخ F مــاه عقـرب سـال جـارى، كَزارش

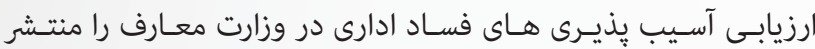

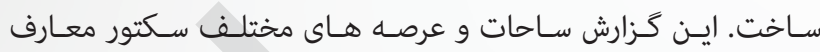

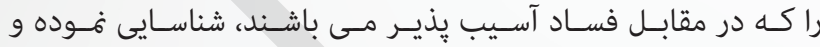

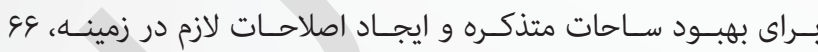
سـفارش مشـخص را بـه وزارت معـارف ارايـه نــود.

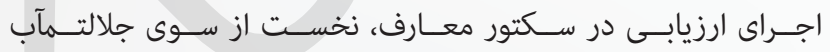

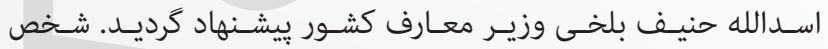

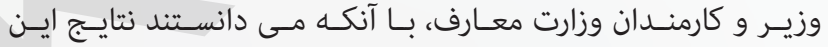

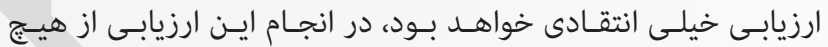

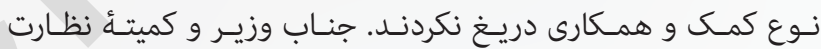

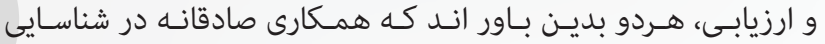

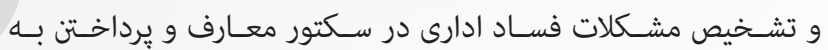

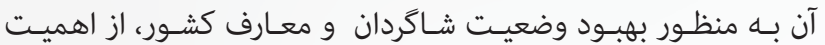

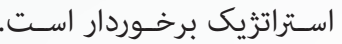

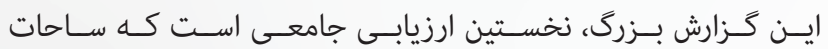

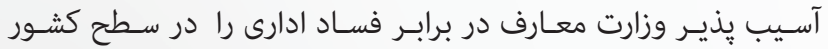

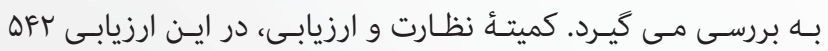

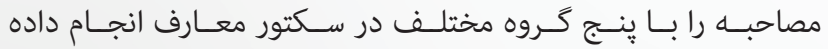

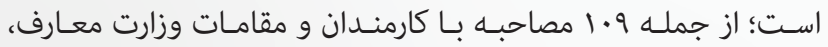

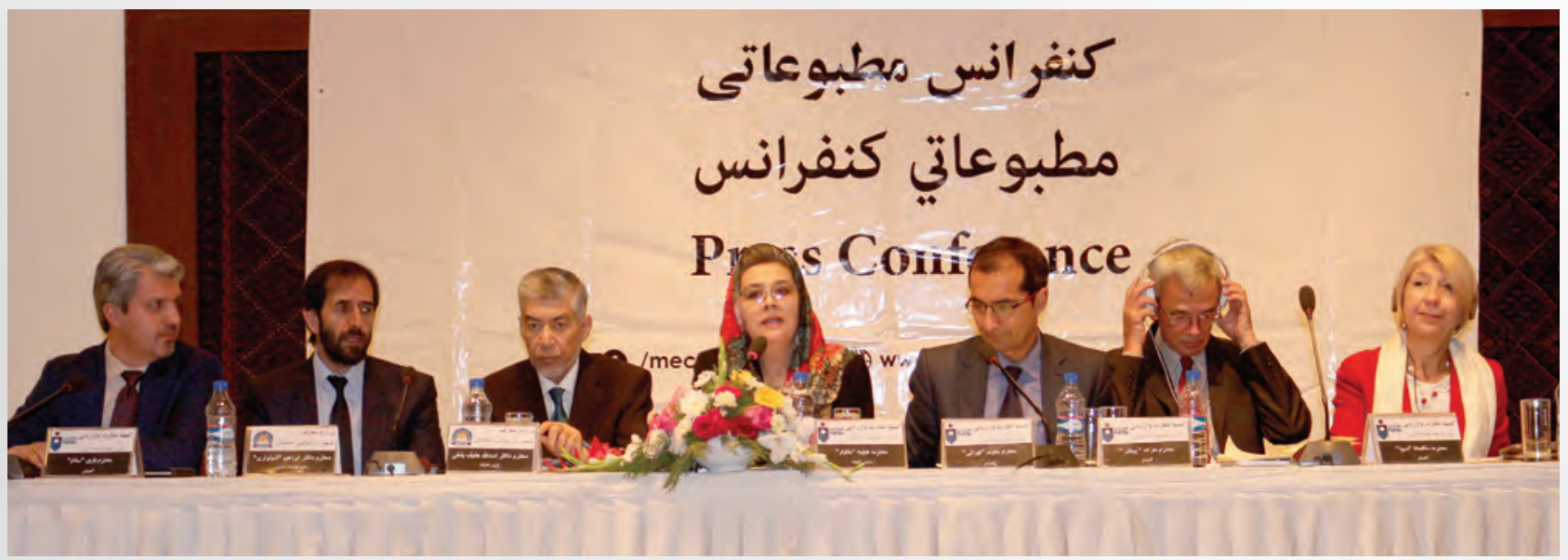


تعيين شده واقع بينانه به نظر نى رسد. از اين رو، معلمين ناكزير

براى كامياب شدن شاكردان در امتحانات، به روش هائ ناد نادرست

متوسل مى شوند.

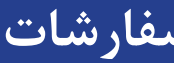

• افزايش مسئوليت و مشاركت محلى در مورد استخدام معلمين، تا

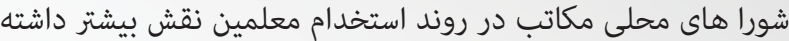

باشند،

• ايجاد يك ادارة مستقل نظارت بر كيفيت معارف؛

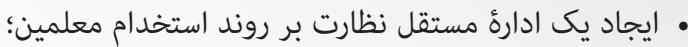

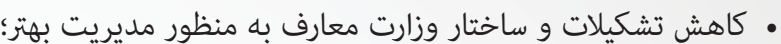

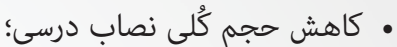
• اجراى هر جه بيشتر قوانين و ارجاع به موقع قضاياى فساد ادارى به

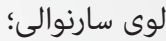
كميتهُ نظارت و ارزيابى يافته هاى كزارش متذكره را با وزارت معارف

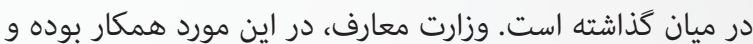
به منظور تطبيق سفارشات روند اجراى يلان مبارزه عليه فساد ادارى مداري خويش را آغاز نهوده اند. كميتهُ نظارت و ارزيابى، اكنون بطور فعالانه از روند تطبيق سفارشات

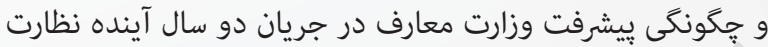

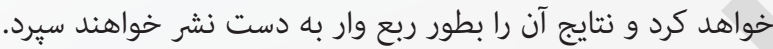

\section{"وزارت معارف به حدى بزرگ}

\section{است كه ( با وضعيت كنونى)}

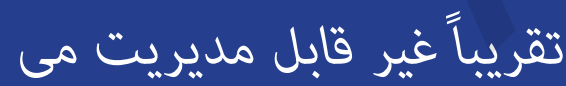

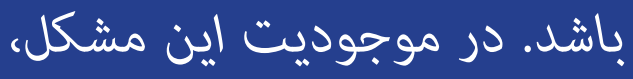

زمينه رشد فساد بيشتر فراهم شده

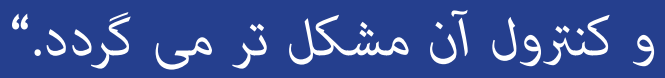

فسـاد قـرار داشـته اســـ.

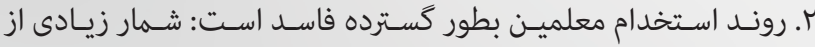

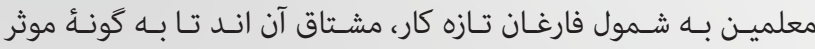
كار و خدمــت فاينـــ. بــا وجــود ايـن، اســتخدام معلميـن در سراسر

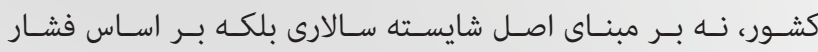

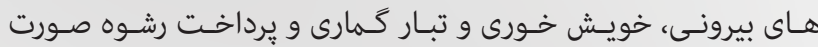

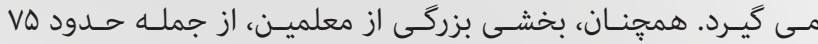

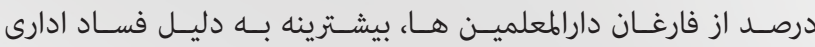

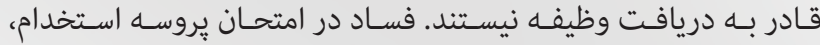

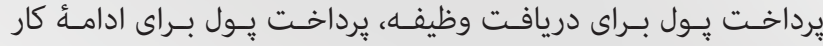

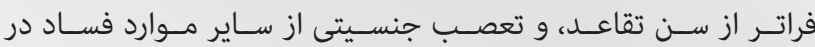

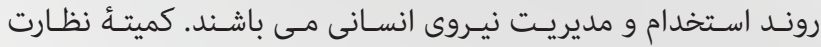

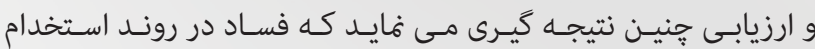

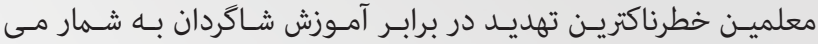

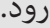

س. فساد كسترده در كتاب هاى درسى، به ويزه در روند توزيع آن:

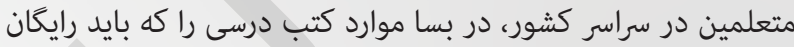
دريافت كنند، خريدارى مى نايند. F. وزارت معارف به حدى بزرى است كه ( با وضعيت كنونى) تقريباً مئد غير قابل مديريت مى باشد. در موجوديت اين مشكل، زمينه رشد

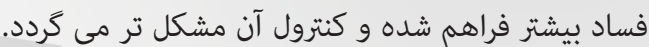
ه. كيفيت تفتيش مكاتب غير موثر بوده و مستقلانه انجام فهى يذيرند.

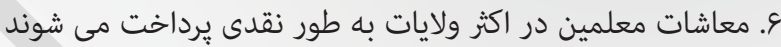

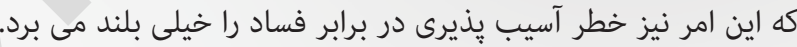
ييشرفت وزارت معارف در مهار اين مشكل خيلى كند است.

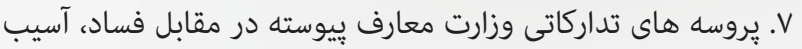
يذير بوده اند. اين موضوع سبب شده است تا شمار زيادى از يروزهه

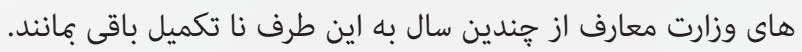
وضعيت ساخت و ساز مكاتب، بايد مورد بررسى مستقل، از جمله مورد نظارت و بررسى تويل كنندكان، قرار گيرند.

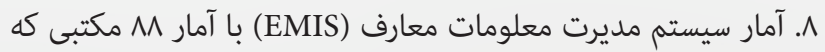
به صورت فونه مورد بررسى قرار گرفته اند، در مورد حاضرى شاكردان،

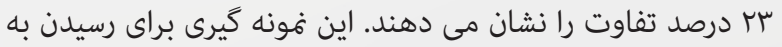

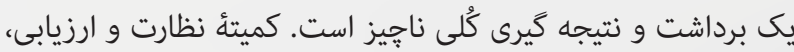
مكاتب ولايات را نتوانست بررسى فايد. ممكن ميزان حاضرى شاكردان در اين مكاتب حتا يايين تر از آن باشد. بهرصورت، مهم آنست كه ياتيت يافته ها از سوى مراجع و افراد كه مسئوليت مرور و بررسى كيفيت و صحت

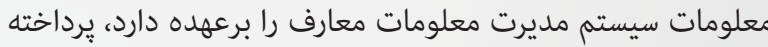
شوند.

9. برنامه سواد حياتى و آموزش بزرگسالان اين وزارت، بطور گسترده

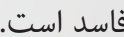
• 1.

مى شود. حجم نصاب درسى در حدى است كه به دوش بسيارى از

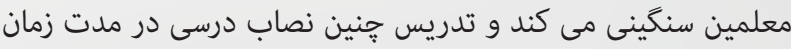




\section{CARD-F تحقيق عامه در مورد برنامة كارد-اف}

اين بى نظمى ها شامل استفاده از شركت هاى قرادادى كه توسط

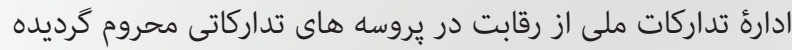

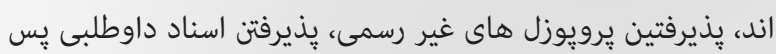

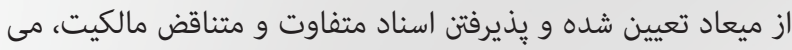

كردند.

r. بودجه مرحلة اول برنامهُ كارد-اف، عمدتاً در اختيار شركت هاى

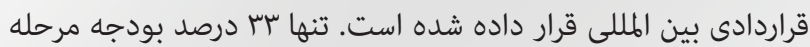

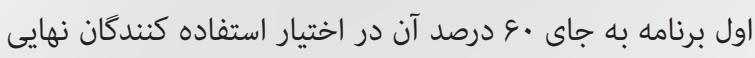

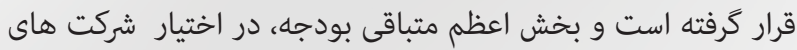

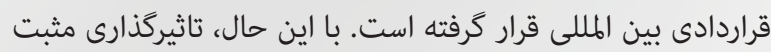

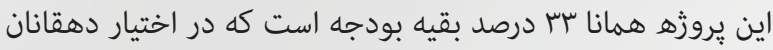

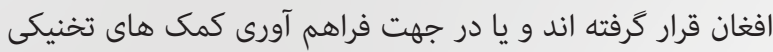

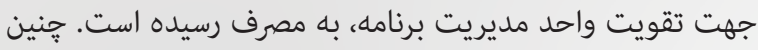

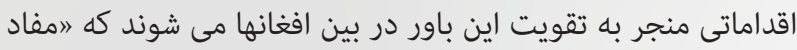

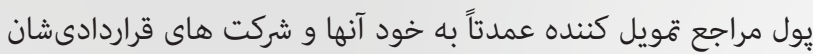

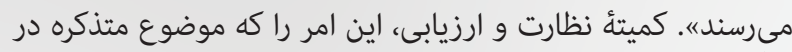
مرحله دوم اين برنامه نيز صدق ميكند يا خير، ارزيابى ننموده است.
كميتهُ نظارت و ارزيابى، نتايج و يافته هاى تحقيق خويش ييرامون اجرآت و تطبيق برنامهُ رشد زراعت و انكشاف دهات (كارد-اف) را به بهافيه تاريخ V عقرب سال روان منتشر نهود.

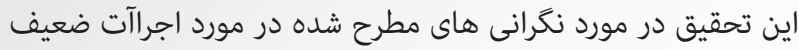

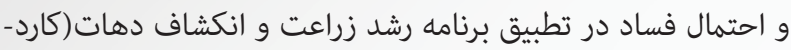

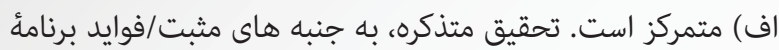

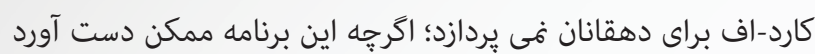

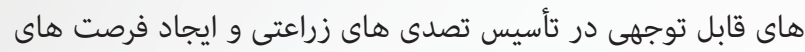
شغلى براى دهقانان افغان داشته باشد.

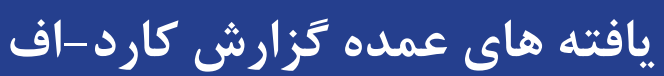

ا. موجوديت خويش خورى و تبار گمارى در واحد مديرت برنامه

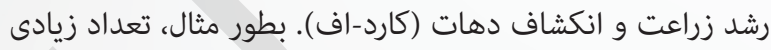

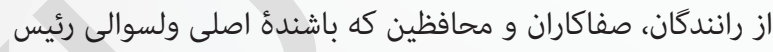

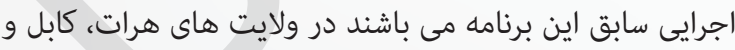

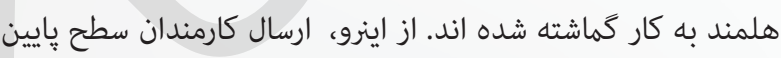

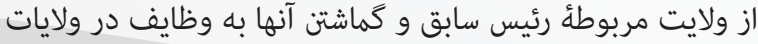

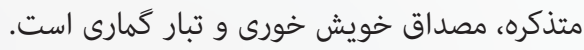

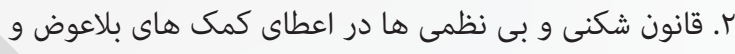

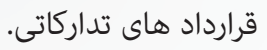

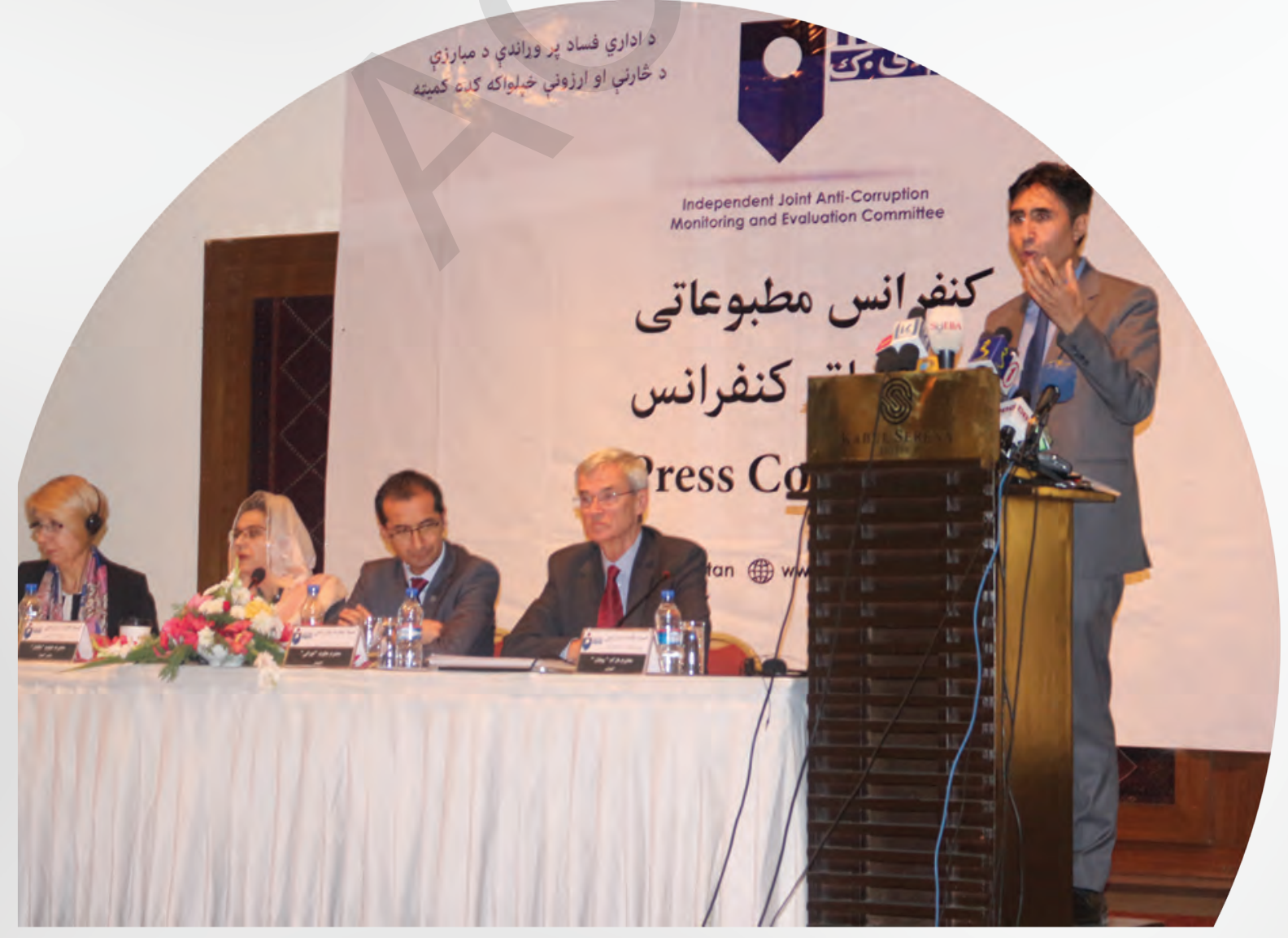




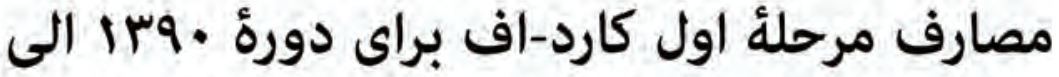

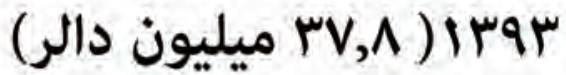

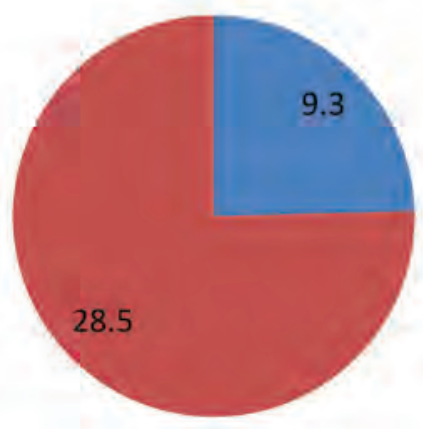

EDP investments

\section{بودجه مرحلهُ اول كارد-اف براى دورة • •جسا الى

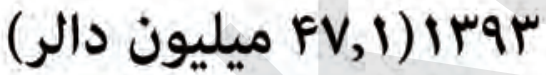

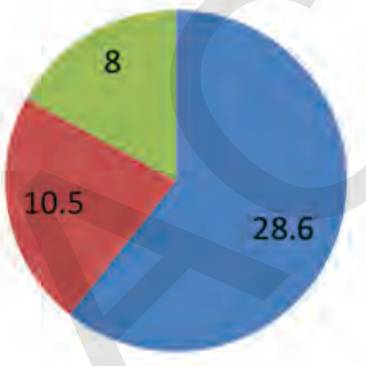

EDP

- Program management

atechnical assistance

F. تضـاد منافـع در فعاليـت هــاى شركـت قـراردادى بيـن امللـى در مرحلـهُ اول برنامـهُ رشـد زراعـت و انكشـاف دهــات(كارد-اف). شركـت

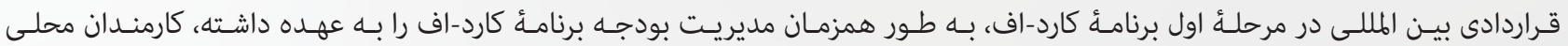

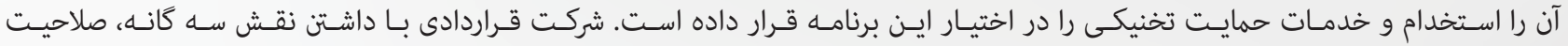

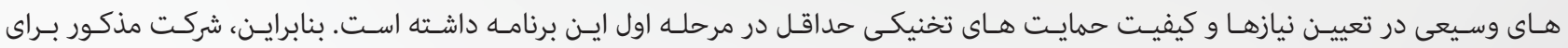

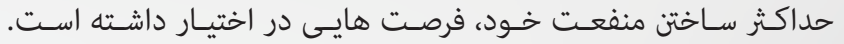

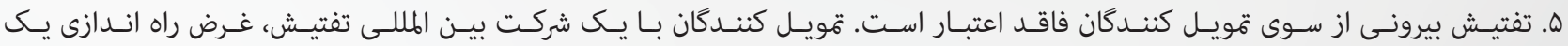

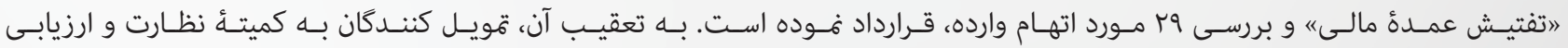

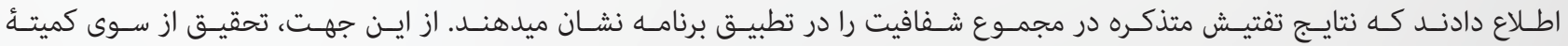

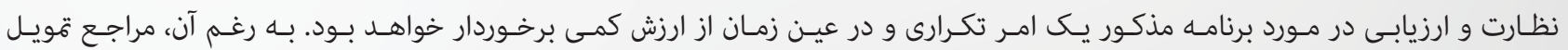

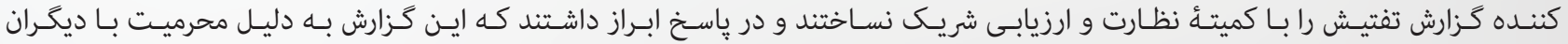

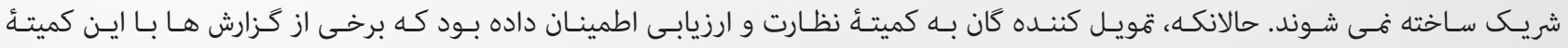

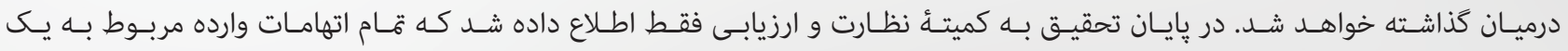




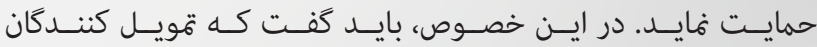

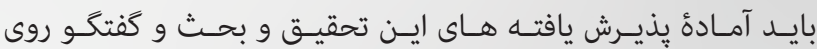

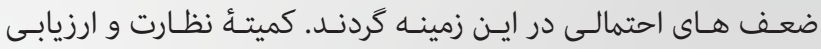

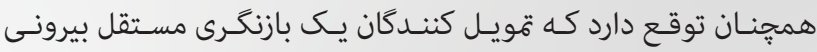

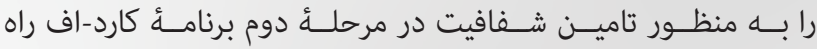
انــدازى فنايـد.

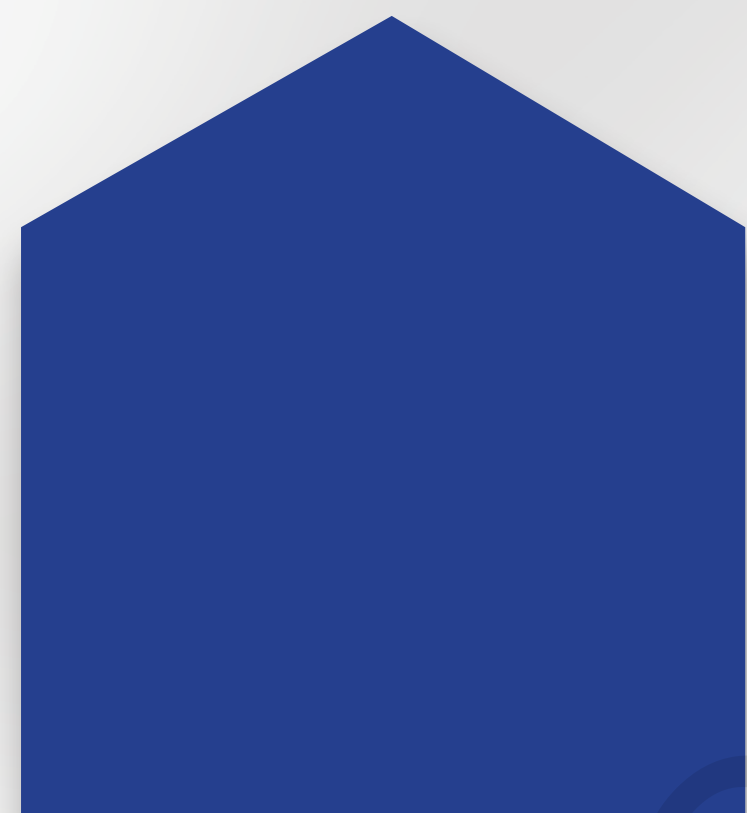

"كميتهُ نظارت و ارزيابى،

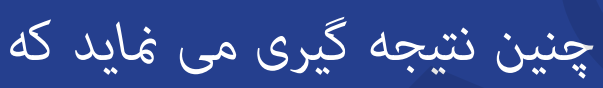

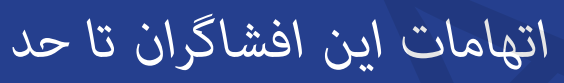

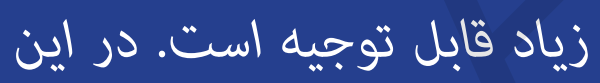

جريان، حد اقل دو افشاكر از تازئ

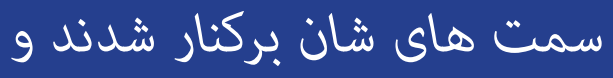

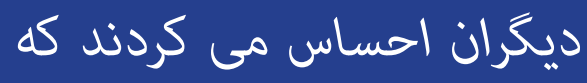

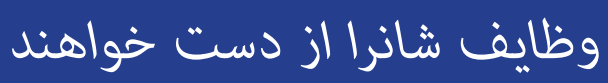

داد
افشـاكر بـوده اسـت.

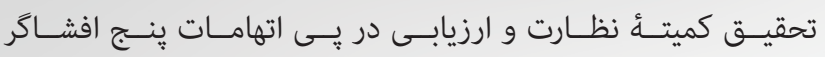

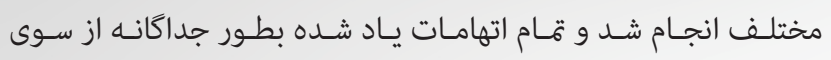

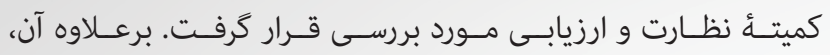

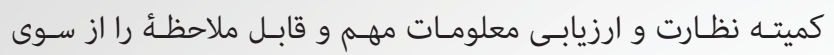

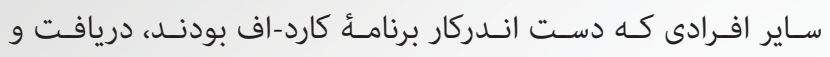

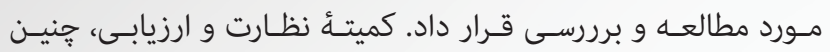

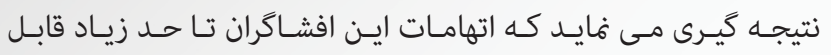

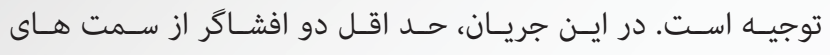

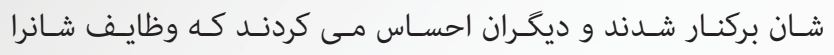

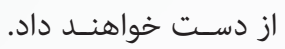

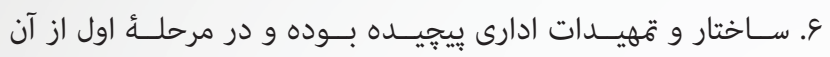

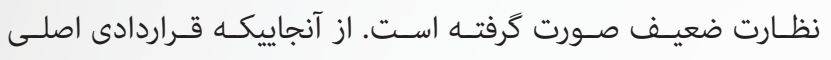

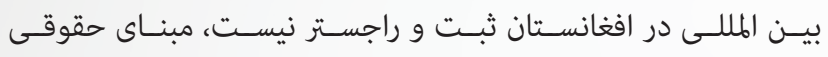

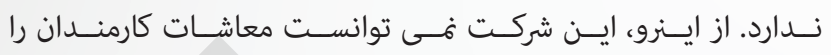

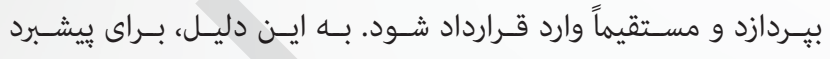

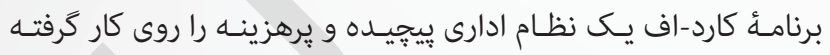

بـود.

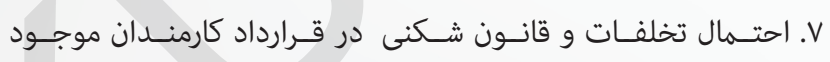

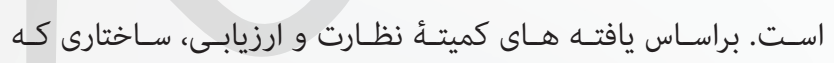

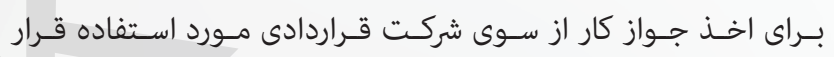

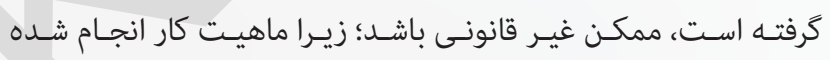

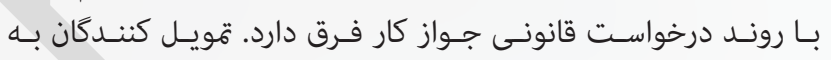

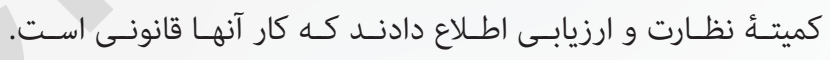

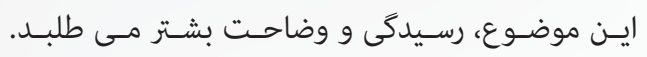

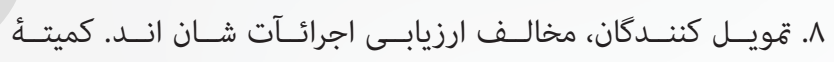

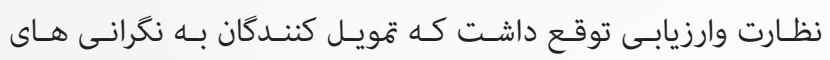

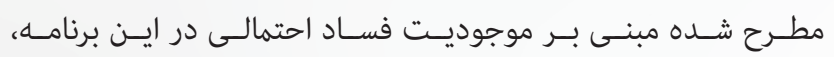

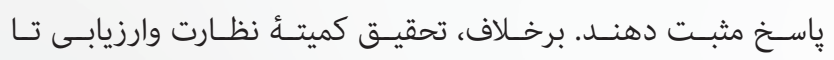

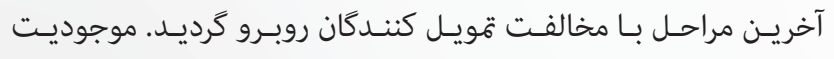

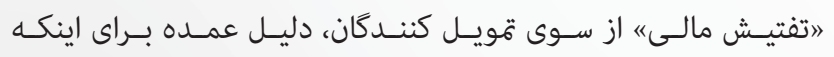

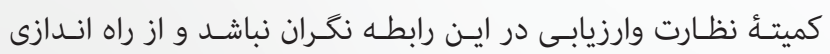

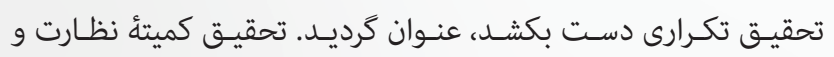

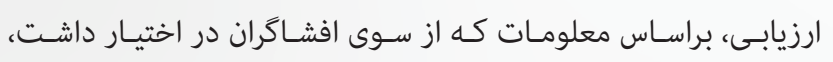

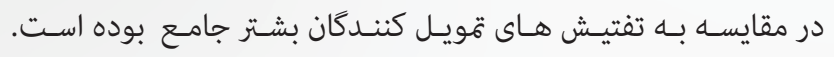

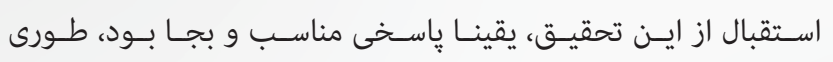

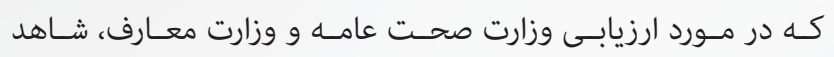

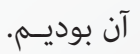

\section{سفار شات}

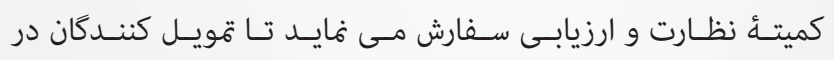

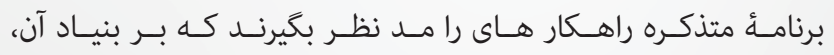

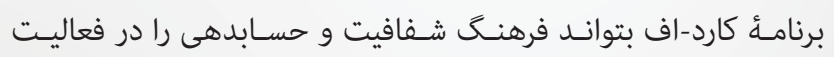

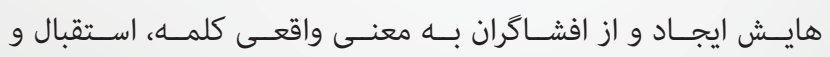




\section{بردى \\ يلان هاى مبارزه عليه فساد ادارى وزارتخانه ها}

"مشاهدات و ارزيابى كلى

كميتُ نظارت و ارزيابى نشان

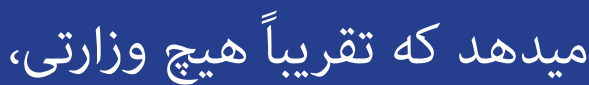

توجه جلى و وقت لازم را به

تدوين و تطبيق يلان مبارزه

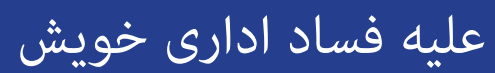

معطوف نكرده است."
كميتــُ نظـارت و ارزيابـى، بررسـى يـلان هـاى مبـارزه عليه فسـاد ادارى

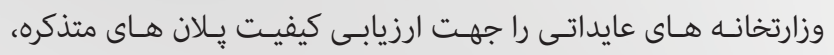

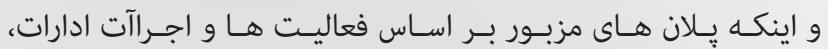

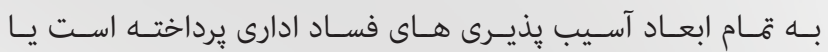

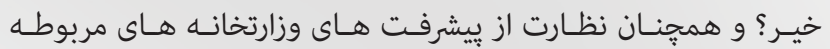

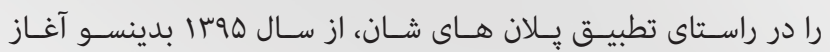

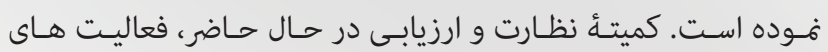

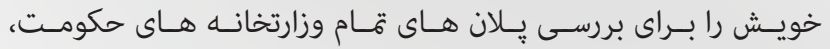

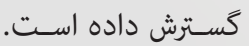

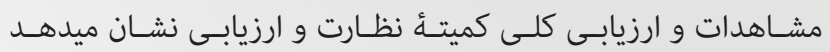

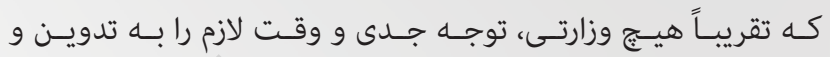

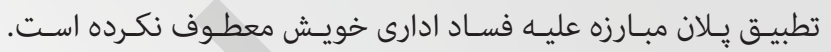

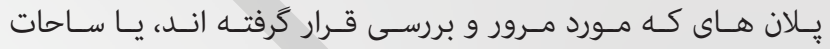

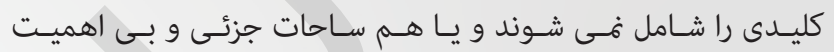

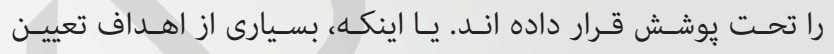

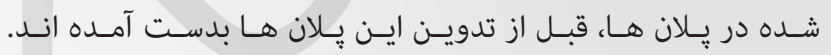

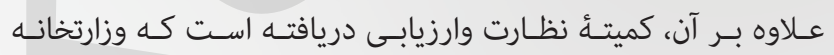

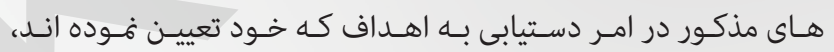

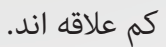

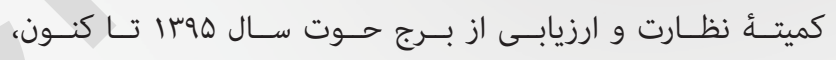

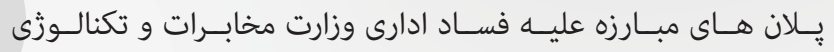

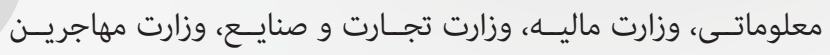

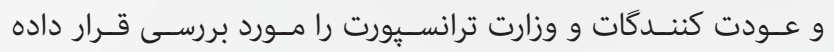

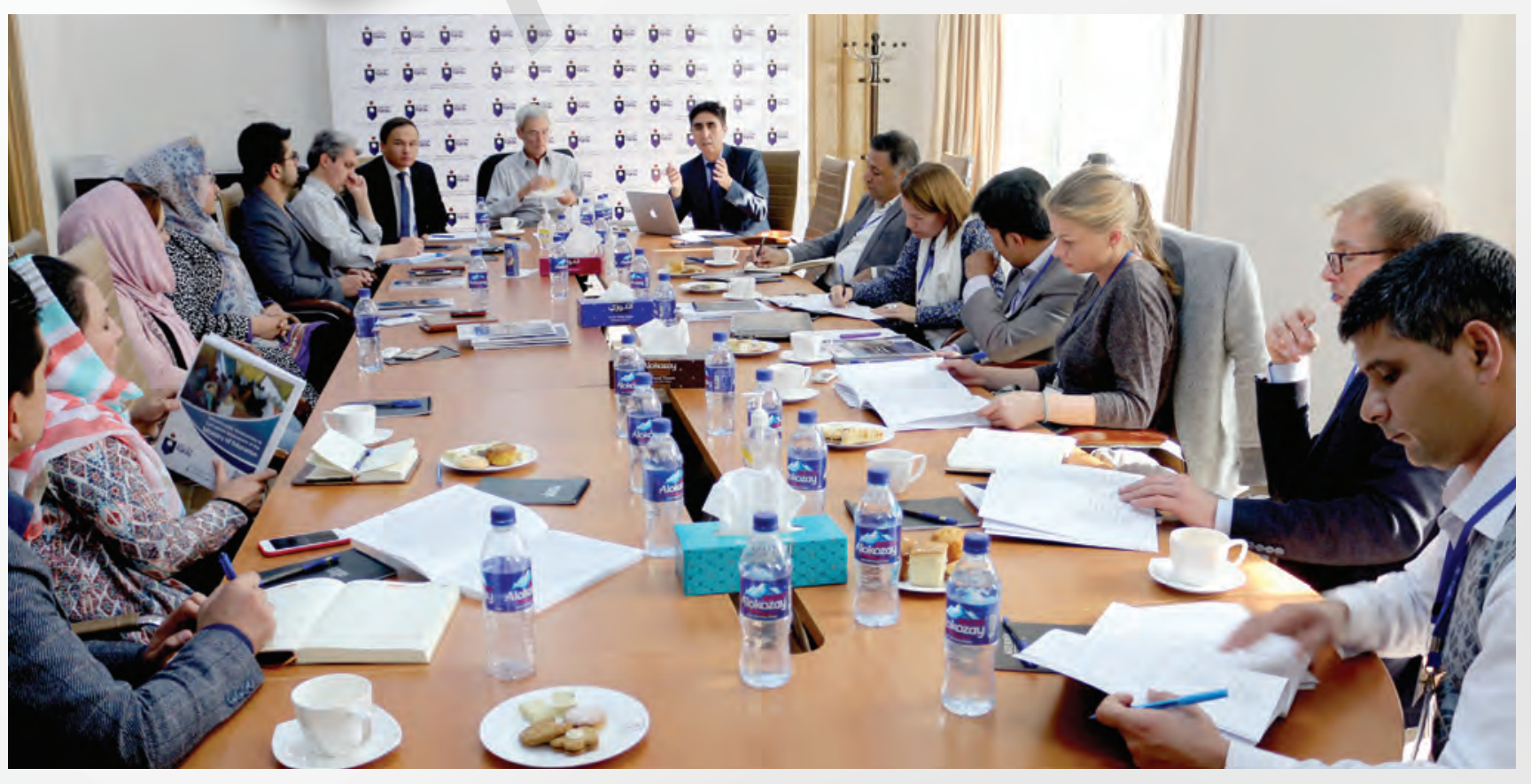




\section{ه مين ماموريت كميتةُ نظارت و ارزيابى}

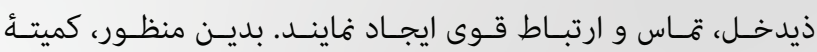

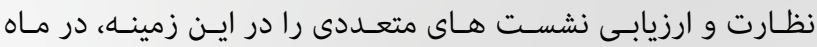

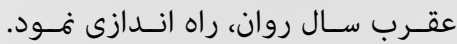

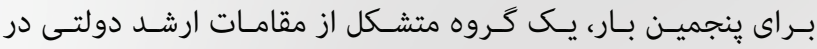

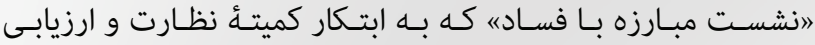

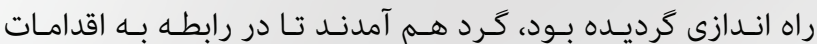

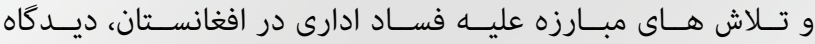

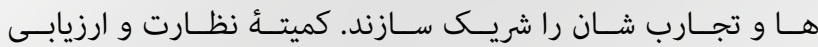

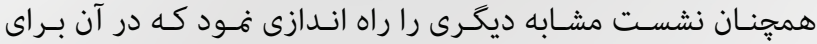

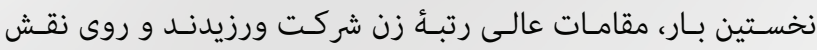

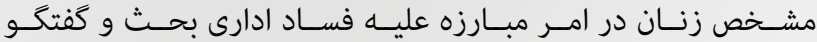

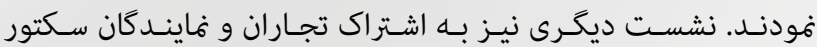

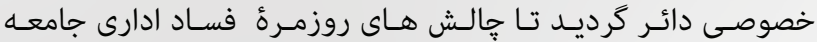

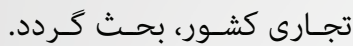

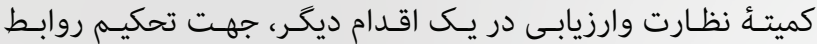

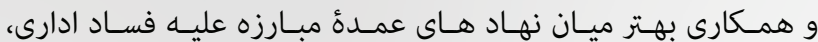

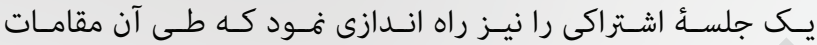

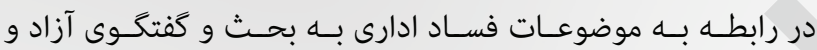

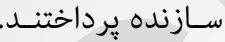

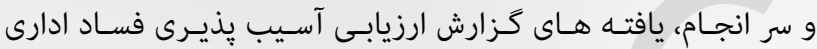

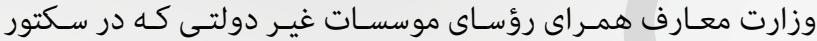

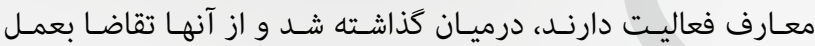

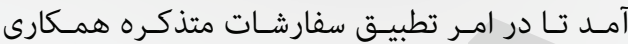

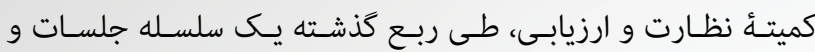

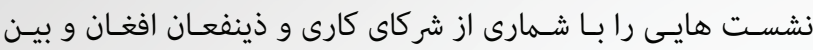

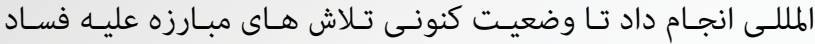

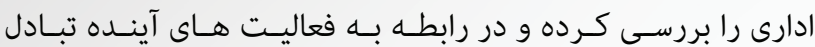

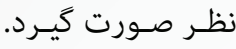

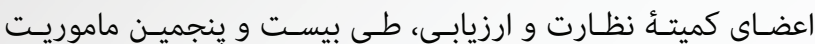

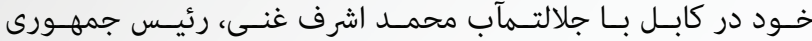

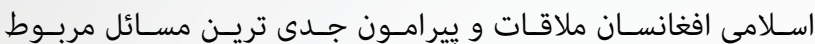

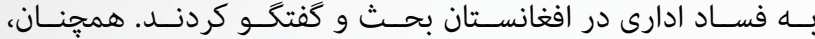

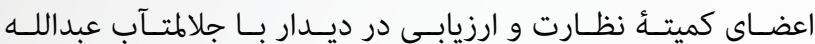

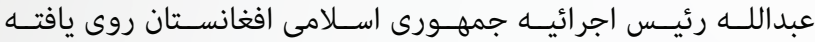

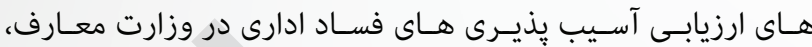

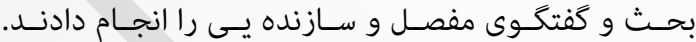

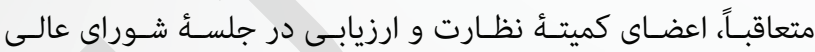

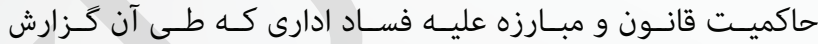

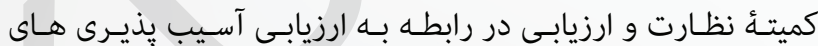

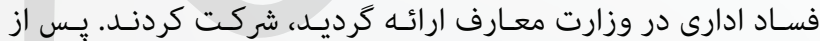

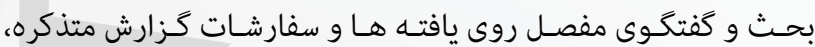

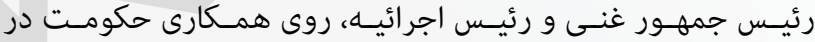

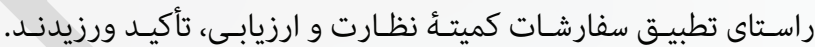

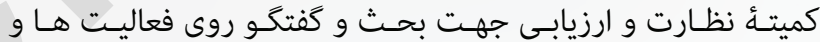

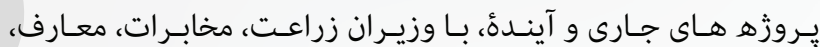

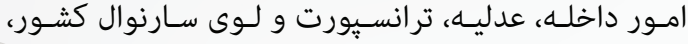

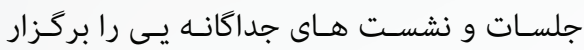

كودند.

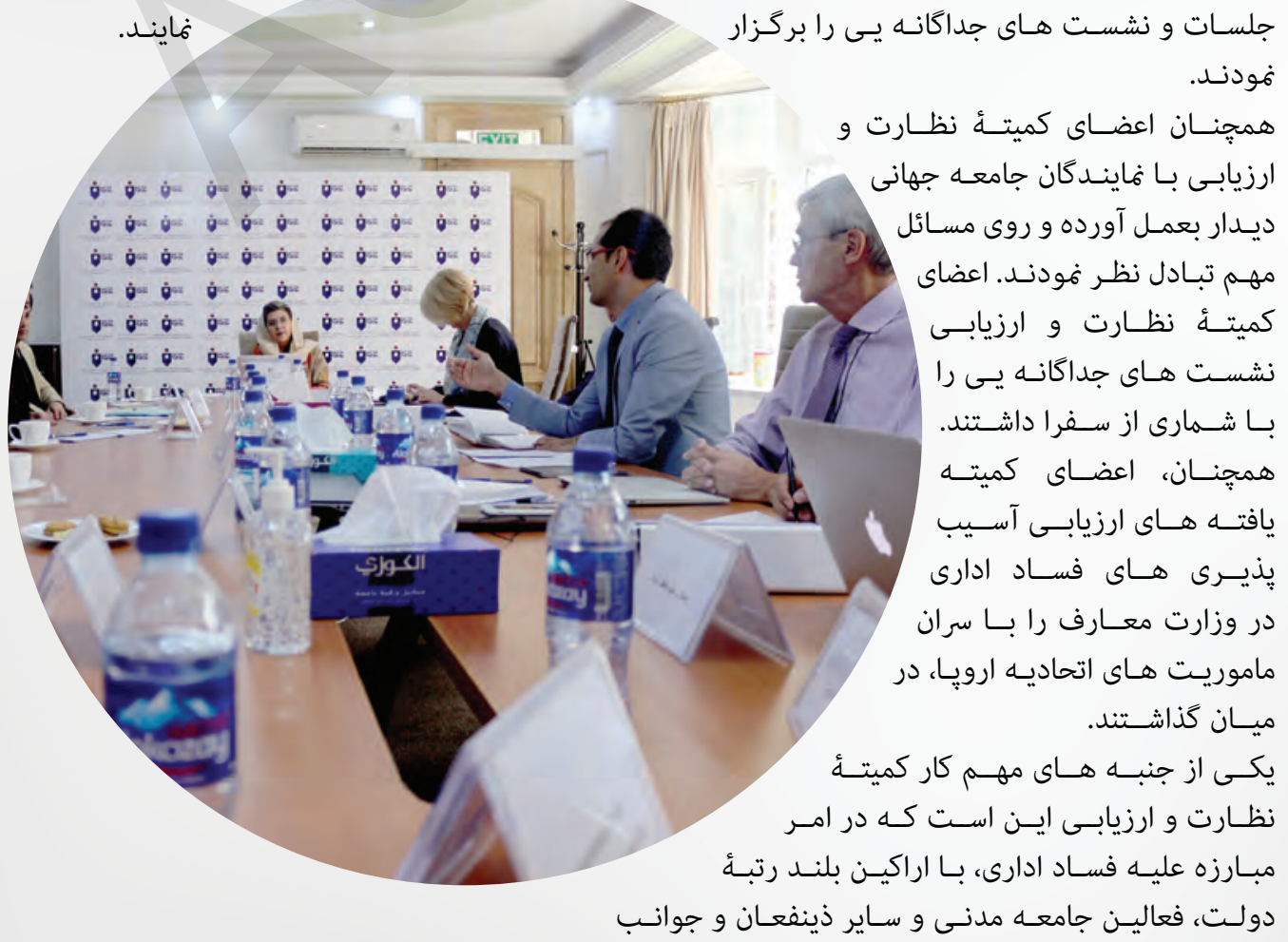




\section{ساير فعاليت هاى ن ماي \\ كميتهُ نظارت و ارزيت هابي}

رئيسـ تخنيكسى كميتـهُ نظـارت و ارزيابـى، بــه تاريـخ 9 ميـزان ســال

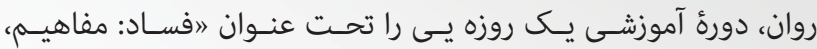

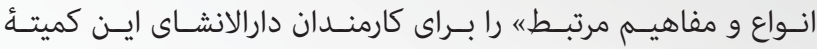

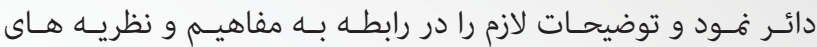
مختلـف فسـاد ادارى، ارائسه كـرد.

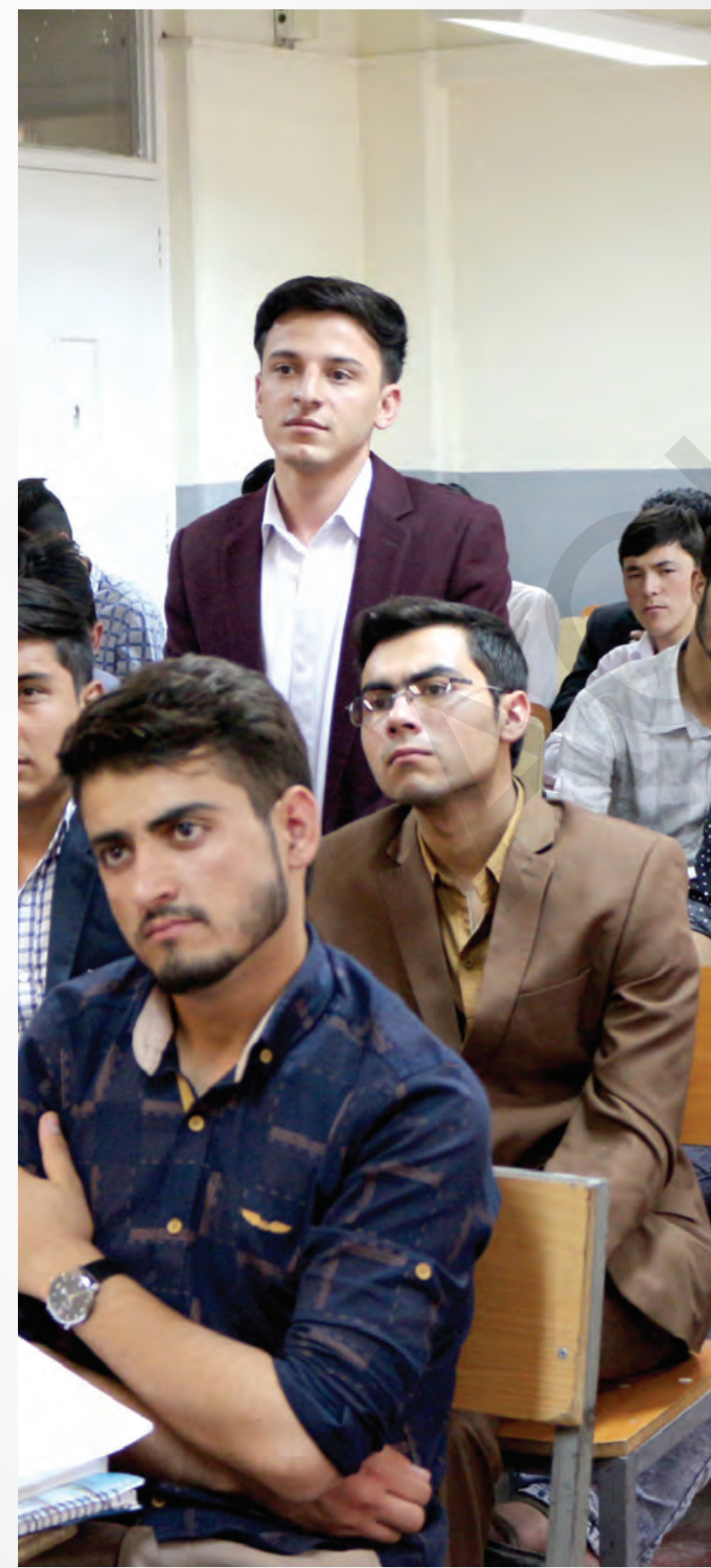

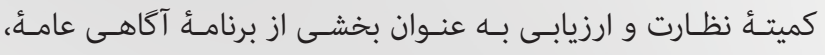

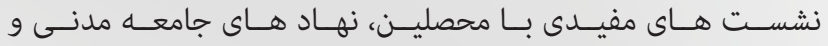

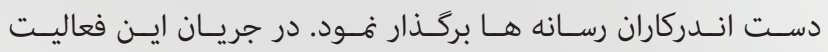

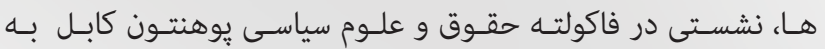

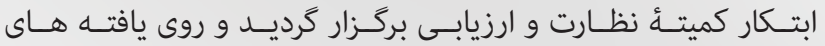

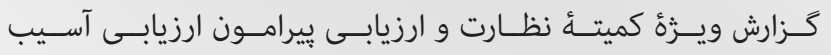

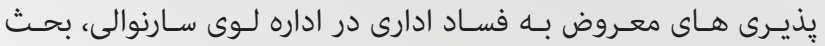

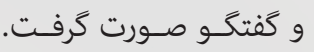

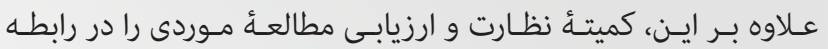

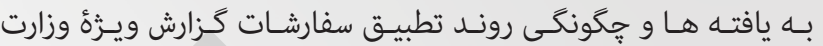

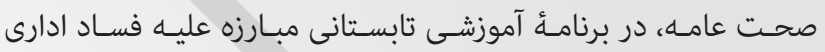

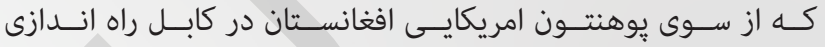

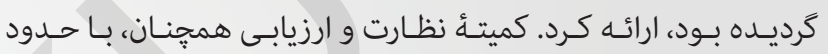

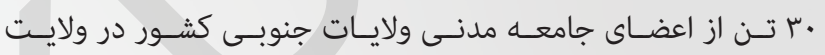

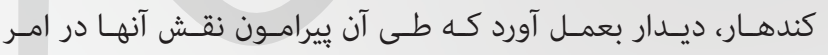

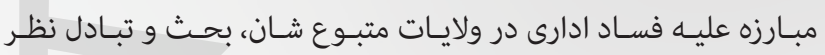
صـورت كرفت.

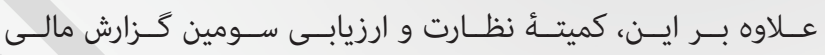

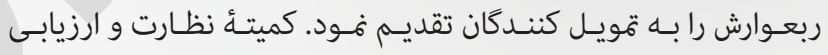

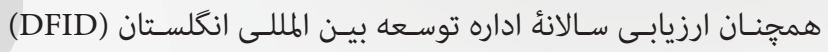

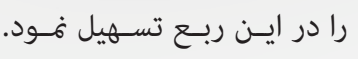

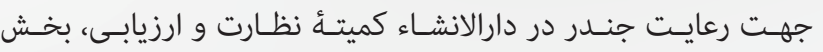

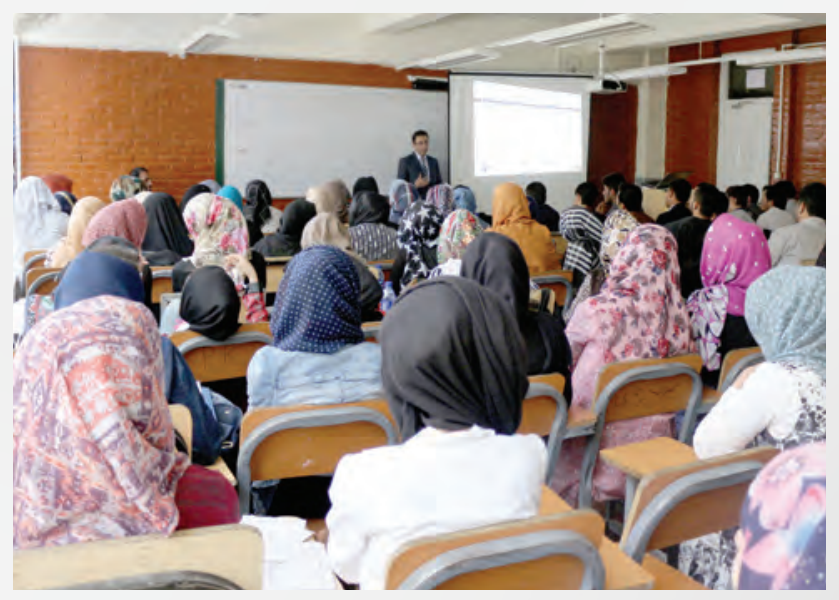

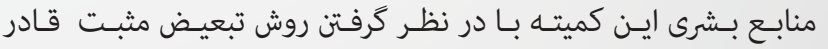

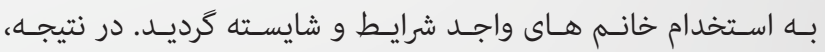

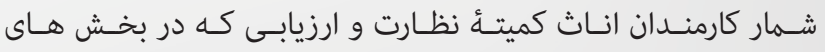

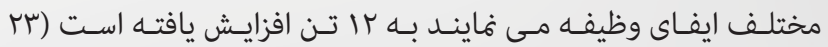

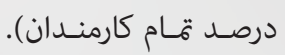




\section{فساد ادارى در افغانستان مرورى بر اخبار اين ربع العاستين}

كرفتـه و محاكمـهـ كرديـده انـد. بــهـ هميـن ترتيـب، موثريــت ســارنوالان در امـر ترتيــبـ و يِيشـــرد

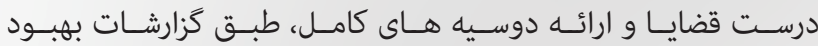

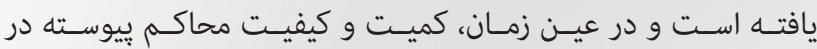

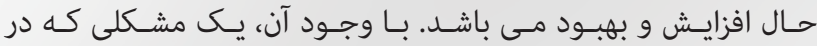

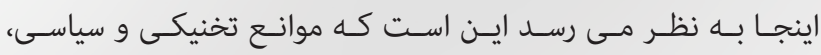

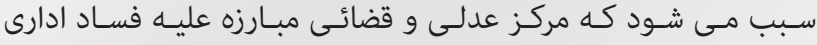

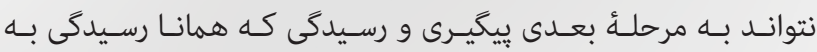

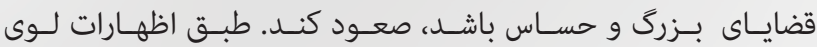
سـارنوالى، محكمــه مركـز عدلى و قضايسى مبـارزه عليـه فسـاد ادارى از

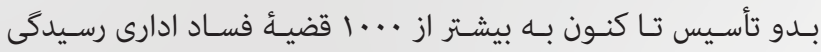

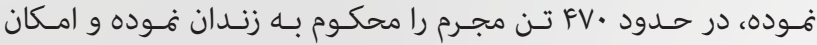

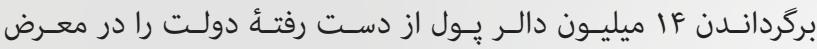

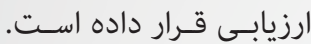

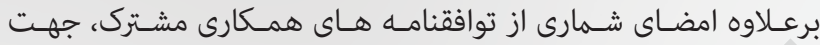

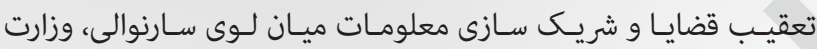

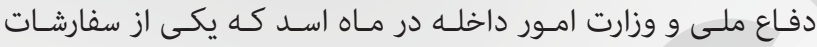

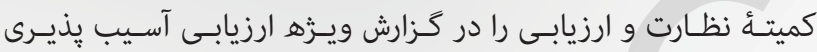

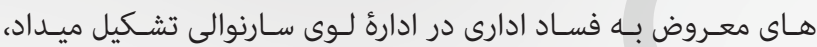

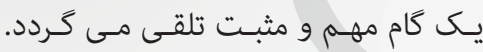

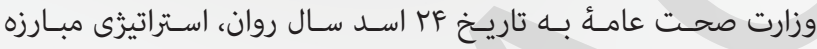

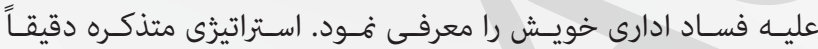

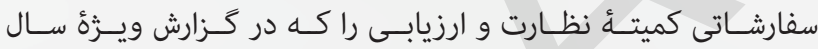

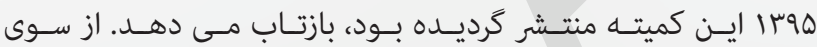

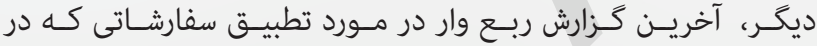

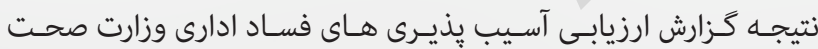

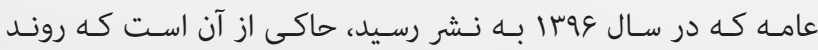

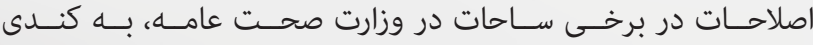

كراييـده اسـت. همجنــان، وزارت ماليــه در مــاه اســــ ســال روان، سيســم آنلايــن

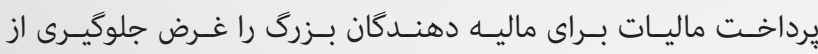

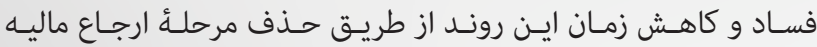

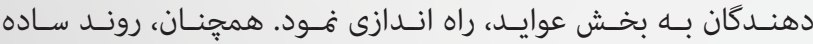

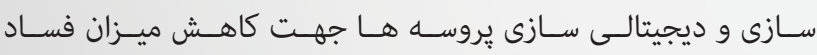
ادارى، در شــاروالى كابـل نيـز ادامــه دارد.

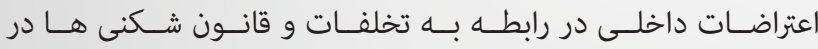

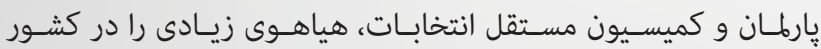

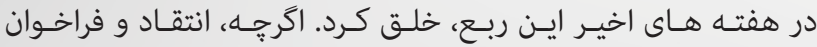

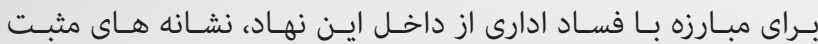

تصويــب اسـتراتيزّى ملـى مبــارزه عليـهـ فسـاد ادارى، مهمتريـن خـبر

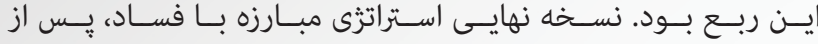

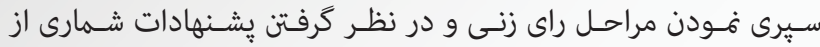

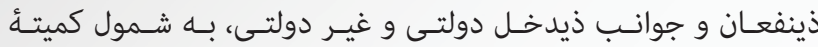

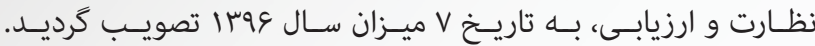

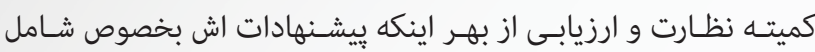

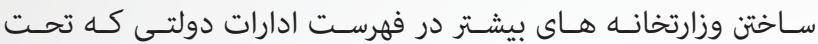

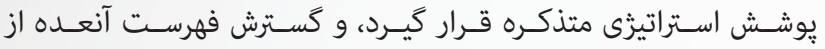

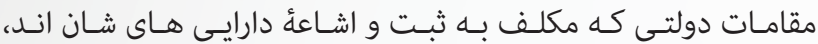

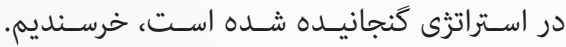

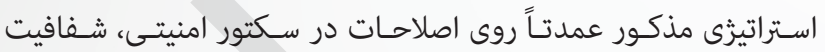

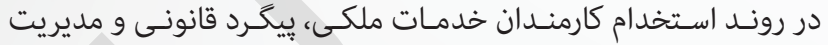

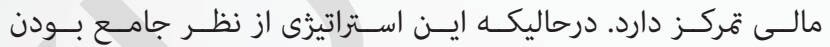

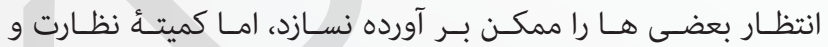

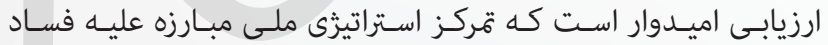

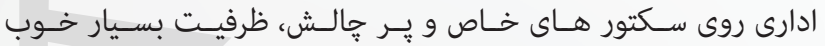

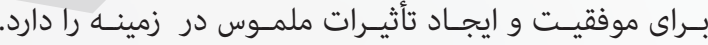

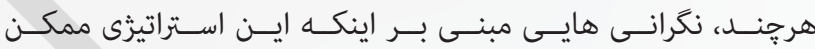

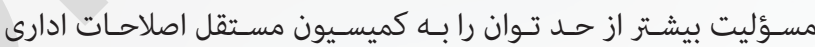
و خدمـات ملكـى واكـذار فمايـد، موجـود اسـت. زيـرا، ايـن كميسـيون

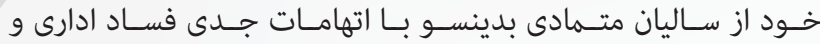

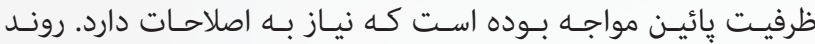

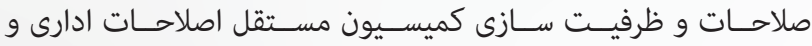

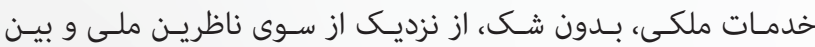

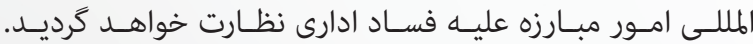
كميسـيون مسـتقل اصلاحـات ادارى و خدمـات ملكى، در ماه اســـ سـال

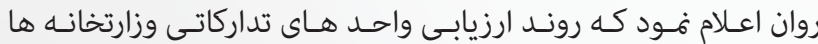

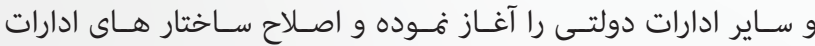

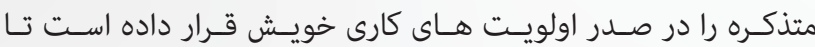
آنهـا را بـا معيـار هــاى جديــد سـازكار فمايـد.

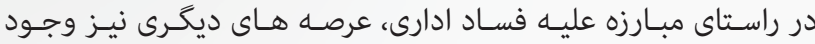

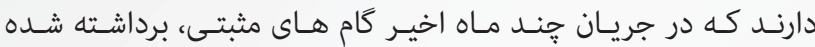

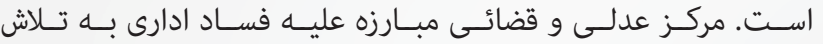

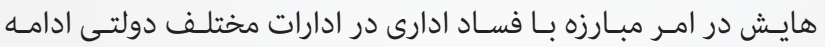

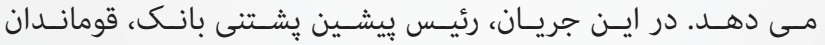

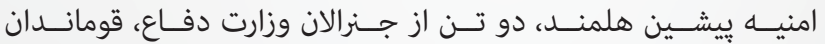

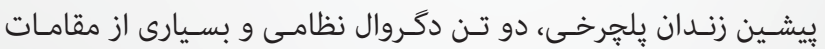

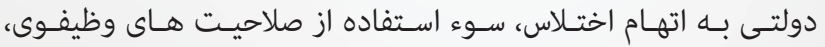
نقـض قانـون، غفلـت وظيفــى و فريبـكارى، مـورد يِيكـرد قانونـى قـرار 


\section{معرفى عضو جديد كميتة نظارت و ارزيابى}

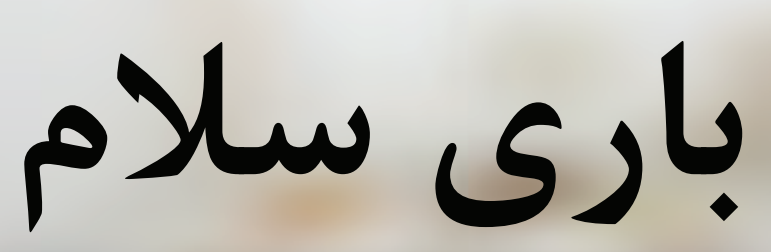

فرهنكـى كـه از سـوى ايـالات متحـده امريـكا تقويـل مـى كـردد، عضويـت آن

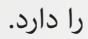

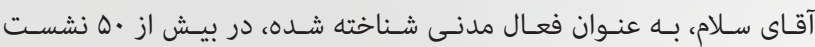

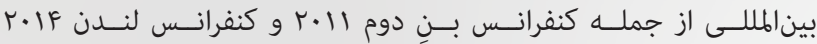

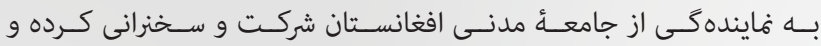

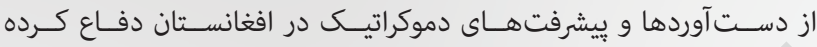

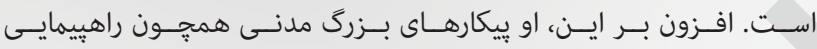

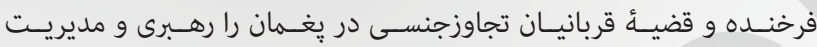

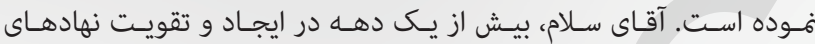

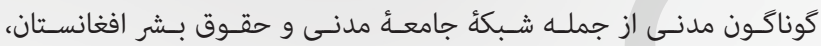

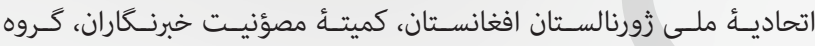

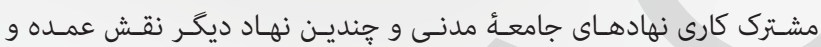
تأثيركـذار داشـته اسـتـ كارئ.

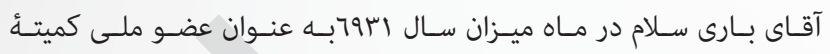

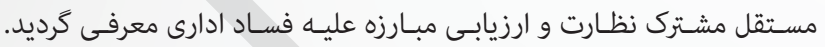

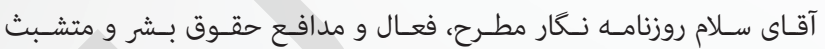

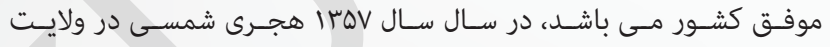

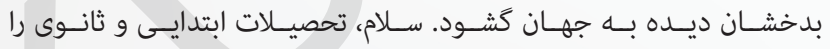

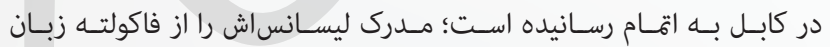

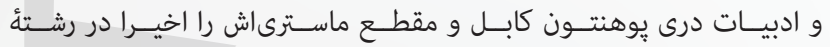

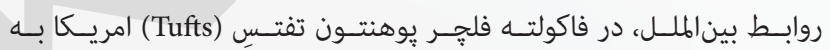

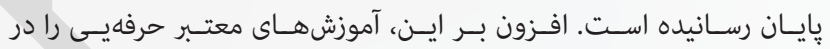

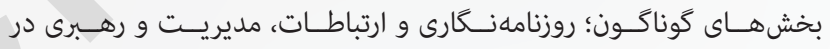

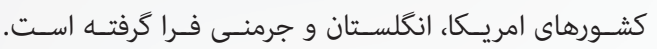

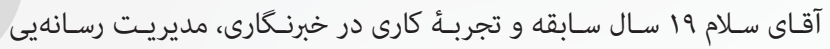

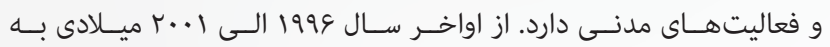

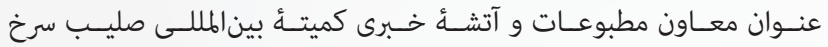

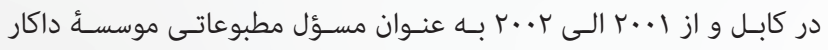

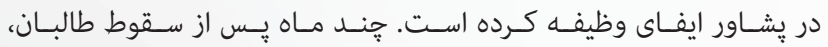

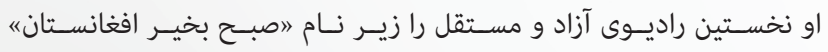

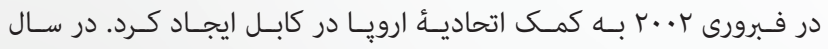

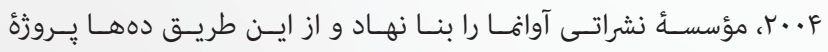

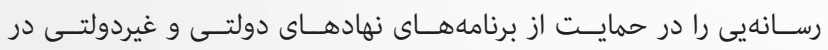

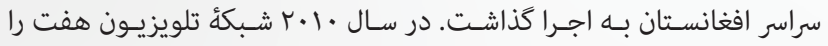

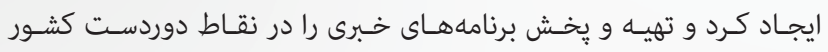

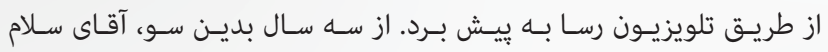

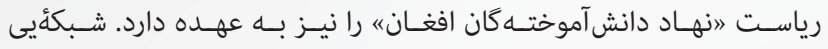

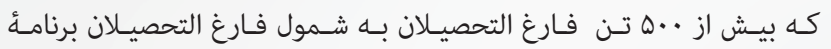

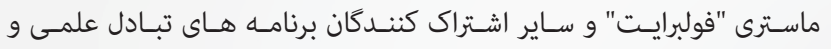

